\title{
The indigenous fortifications of South Sulawesi, Indonesia, and their sociopolitical foundations
}

\author{
David Bulbeck and lan Caldwell
}

\section{Introduction}

This contribution brings together the historical and archaeological evidence for the Indonesian province of South Sulawesi (Figure 7.1) relevant to current debates on the development of fortifications in the Indo-Pacific region during the second millennium AD. The province of South Sulawesi is well placed for this task because of indigenous written historical traditions that cover much of the period of interest (Caldwell 1988: 171), and European accounts from the early sixteenth century onwards (Pelras 1977). In addition to archaeological surveys of historical sites undertaken across much of the province (Table 7.1), a cluster of fortifications near Bone's capital of Watampone have been recorded in sufficient detail for inclusion here (Appendix K). ${ }^{1}$

South Sulawesi's diversity of agro-climatic regimes provides a unique insight into proposals that link fortification development with resource availability and climatic stress. The climate varies from perhumid and equatorial north of the Gulf of Bone, associated with sago production, to monsoonal across the peninsula. Between May and late July, the eastern part of the peninsula experiences a mild rainy season, while the southern and western peninsula enjoys a dry season of increasing aridity from the north to the south. As one approaches the south coast, where several months may pass without rain, the landscape turns from green to brown. Between October and April the eastern side of the peninsula and Selayar Island experience a dry season marked by occasional, local rainfall, while on the west side an ample monsoon starts in December and continues through to late February. Rainfall along the peninsula's coastal cordilleras either drains to the coast or fills the Walennae River and inundates the central lowlands where the Walennae and Cenrana rivers meet (Bulbeck 1992). Bunded rice paddies dominate the rural landscape around the central lowlands and along the coastal plains. In highland or drier regions where the possibility of rice production is limited, arboriculture, maize and root crops are important. Sources of protein include poultry, goats, cattle, and sea and freshwater fish.

1 This contribution covers archaeological fieldwork and textual research up to 2012, when the original manuscript was submitted for intended publication. Subsequent related studies are not considered here. 


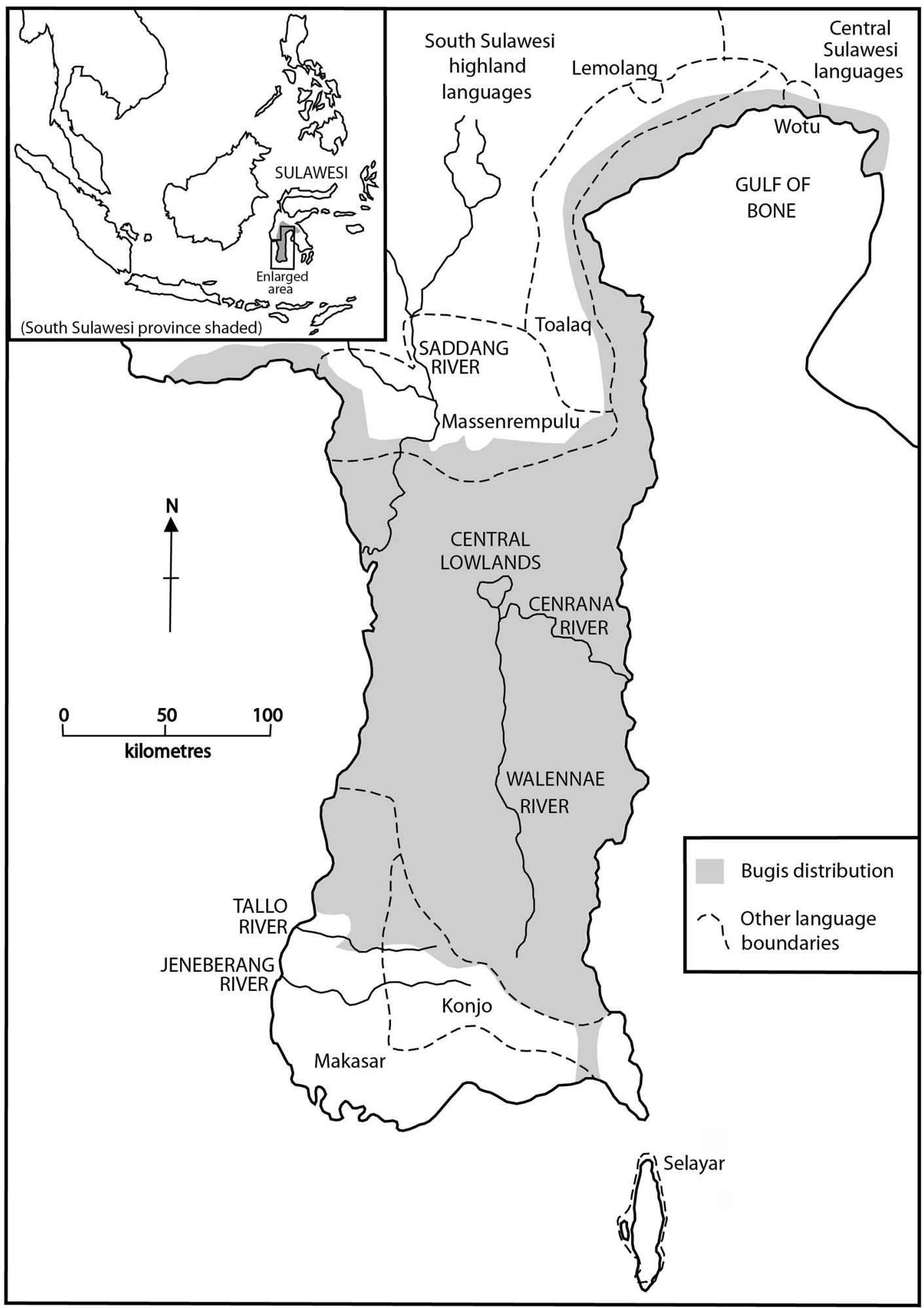

Figure 7.1. South Sulawesi: main topographical features and language boundaries.

Source: David Bulbeck (after Grimes and Grimes 1987: Map 3; Druce 2009: Figure 3.21; OXIS Group 2020). 
Table 7.1. Locations (north to south) surveyed in South Sulawesi for historical sites.

\begin{tabular}{|c|c|c|c|c|}
\hline $\begin{array}{l}\text { Surveyed city/ } \\
\text { regency/regencies }\end{array}$ & Target site(s) & Sampling strategy & $\begin{array}{l}\text { Approximate } \\
\text { chronological } \\
\text { coverage (AD) }\end{array}$ & Reference(s) \\
\hline $\begin{array}{l}\text { North and East } \\
\text { Luwu }\end{array}$ & Iron-industry related sites" & Local reports/surface survey & 1st-20th Cs & $\begin{array}{l}\text { Bulbeck and Caldwell } \\
2000\end{array}$ \\
\hline Palopo city, Luwu & Tompotikka fort & Surface survey & 16th-19th Cs & Mahmud 1993 \\
\hline $\begin{array}{l}\text { Enrekang (central } \\
\text { Saddang River) }\end{array}$ & $\begin{array}{l}\text { Mortuary sites; } \\
\text { fortifications }\end{array}$ & Local reports/surface survey & 17th-20th Cs & $\begin{array}{l}\text { Makkulasse 1986; } \\
\text { Somba 2009, } 2010\end{array}$ \\
\hline $\begin{array}{l}\text { Pinrang, Suppa, } \\
\text { Sidenreng Rappang }\end{array}$ & Pre-Islamic sites & Local reports/surface survey & 13th-19th Cs & Druce 2009 \\
\hline Рare-Рare city & Bacukiki site complex & Local reports/surface survey & 17th-19th Cs & Muhaeminah 2010 \\
\hline Ваггu & Islamic heritage sites & Local reports/surface survey & 17th-20th Cs & Masdoeki 1984 \\
\hline Wajo & $\begin{array}{l}\text { Tosora fort; nearby } \\
\text { settlements: }\end{array}$ & Local reports/surface survey & 17th-19th Cs & $\begin{array}{l}\text { Kallupa 1985; Nur and } \\
\text { Hakim } 2010\end{array}$ \\
\hline Soppeng & Pre-Islamic sites & $\begin{array}{l}\text { Textual toponyms/surface } \\
\text { survey }\end{array}$ & 13th-19th Cs & Kallupa et al. 1989 \\
\hline Cenrana Valley & Historical sites" & $\begin{array}{l}\text { Textual toponyms/surface } \\
\text { survey }\end{array}$ & 13th-18th Cs & $\begin{array}{l}\text { Mahmud 2000; Bulbeck } \\
\text { and Caldwell } 2000\end{array}$ \\
\hline Lamuru & Lamuru Islamic cemetery & Surface survey/restoration & 17th-19th Cs & Muttalib 1978 \\
\hline Pangkajene & Sengkae fort" & Textual toponym & 15th-17th Cs & $\begin{array}{l}\text { Fadillah and Mahmud } \\
2000\end{array}$ \\
\hline Sinjai & $\begin{array}{l}\text { Hilltop sites; Balangnipa } \\
\text { fort }\end{array}$ & Local reports/surface survey & 14th-19th Cs & $\begin{array}{l}\text { Kallupa 1984; } \\
\text { Muhaeminah 2009; } \\
\text { Hasanuddin in press }\end{array}$ \\
\hline $\begin{array}{l}\text { Makassar and } \\
\text { hinterland }\end{array}$ & 17th-C. and earlier sites & $\begin{array}{l}\text { Textual toponyms/local } \\
\text { reports/surface survey }\end{array}$ & 13th-19th Cs & Bulbeck 1992 \\
\hline Takalar & Islamic heritage sites & Local reports/surface survey & 17th-19th Cs & Masdoeki 1985 \\
\hline Bulukumba & Historical sites & Local reports/surface survey & 14th-20th Cs & Muttalib 1983 \\
\hline Bantaeng & $\begin{array}{l}\text { La Tenri Ruwa Islamic } \\
\text { cemetery; pre-Islamic sites }\end{array}$ & $\begin{array}{l}\text { Local reports/surface } \\
\text { survey/restoration }\end{array}$ & 11th-19th Cs & $\begin{array}{l}\text { Muttalib 1980; Bougas } \\
\text { 1998; Fadillah 1999; } \\
\text { Nayati } 2000 \\
\end{array}$ \\
\hline Jeneponto & Pre-Islamic sites & Local reports/surface survey & 13th-16th Cs & $\begin{array}{l}\text { Caldwell and Bougas } \\
2004\end{array}$ \\
\hline Selayar & $\begin{array}{l}\text { Pre-Islamic sites; Buki } \\
\text { kingdom }\end{array}$ & Local reports/surface survey & 12th-18th Cs & $\begin{array}{l}\text { Wibisono 1985; } \\
\text { Muhaeminah and } \\
\text { Mahmud } 2009\end{array}$ \\
\hline
\end{tabular}

"Fieldwork investigations included extensive excavation as well as documentation of surface remains.

Sources: See references throughout table.

The people of South Sulawesi are conventionally divided into three major linguistic groups, although in reality the situation is more complex. The Bugis are the most numerous with a population of approximately 4 million, followed by the Makasar with a population of approximately 2.5 million. ${ }^{2}$ The highland-dwelling Toraja groups living along the Saddang River and its tributaries have been little investigated in terms of their historical archaeology (apart from the Massenrempulu region) and need not concern us here. The distribution of the Bugis (Figure 7.1) suggests that over time they have infiltrated the homelands of neighbouring ethnic groups, including speakers of Massenrempulu, Toalaq and Central Sulawesi languages (including

2 Broad figures extrapolated from Indonesia's Population Census (Sudarti Surbakti et al. 2000) and CIA World Factbook. Speakers of languages belonging to the Makasar group include 200,000 Konjo and 90,000 speakers of Selayar (Grimes and Grimes 1987:28-29). 
Padoe) to the north, and the Makasar and Konjo languages to the south. In terms of religious affiliation, the Bugis and Makasars have by and large converted to Islam, beginning around AD 1600.

South Sulawesi offers a wealth and variety of fortifications, varying from simple earth mounds (formerly supporting defensive fences of iron or bamboo) set around modest habitation sites to brick fortresses enclosing areas of up to 84 hectares, and earthen fortresses enclosing areas of up to $2 \mathrm{~km}^{2}$. The scattered literature on these fortifications (e.g. Perelaer 1872; Andaya 1981; Bulbeck 1998) has generally endeavoured to link them to particular military conflicts, without any attempt to synthesise the wealth of relevant historical and archaeological evidence within a general framework of armed combat and political centralisation in South Sulawesi during the second millennium $\mathrm{AD}$.

In synthesising this evidence, we are in a position to test the model for Indo-Pacific fortifications proposed by Field. According to Field (2008:3-4), the construction of fortifications as the defended occupation of a settled location can be expected at locations with resources that are densely distributed and temporally predictable. Further, during periods of climatic unpredictability, one can expect increased conflict between these settled populations, stimulating the construction of additional fortifications and strengthening of existing fortifications. One such period of climatic unpredictability across much of the Indo-Pacific, according to Field (2008:6), would have been the 'Little Ice Age' after c. AD 1300.

East Timor is the closest place to South Sulawesi where an association between climatic unpredictability and fortification construction has been investigated. During the middle second millennium AD, north coastal East Timor witnessed a remarkable phase of indigenous fort construction involving the building of hundreds of stone-walled structures on hilltops and cliff edges, the remains of which are still visible today. Lape and Chao (2008) relate this phenomenon to a dramatic shift in landscape use and settlement patterns after AD 1000 and propose a causal link between fortification building and a hypothesised period of reduced rainfall associated with ENSO (El Niño Southern Oscillation). They argue that a drying of Timor's climate after c. AD 1000 and the consequent unpredictability of rainfall-dependent resources produced social stresses that stimulated the building of hilltop forts (Lape and Chao 2008:12). ${ }^{3}$

Despite the physical proximity of South Sulawesi and East Timor, their climates are very different. North coastal East Timor is one of the driest regions in Island Southeast Asia, as it falls within the 'permanently dry' zone characterised by 9 to 12 months a year that receive an average rainfall of less than $100 \mathrm{~mm}$. The closest similarity in South Sulawesi is the 'seasonally dry' pockets in the southwest and southeast corners of the peninsula, and the island of Selayar, which on average receive less than $100 \mathrm{~mm}$ a month for 5 to 8 months a year (Monk et al. 1997: Figure 2.17). The greater susceptibility to drought of north coastal East Timor means that the ENSO-focused model of Lape and Chao (2008) would not be expected to apply to the parts of South Sulawesi that experience more reliable rainfall. Nonetheless, with reference to Field's (2008:4-6) overarching model, we would still expect to see an increase in fortification construction related to climatic unpredictability after AD 1300 and particularly between the sixteenth to eighteenth centuries.

3 Lape and Chao base their climatic reconstruction largely on a proxy record from Ecuador that indicates 'a dramatic increase in El Nińo events well above modern levels from 1100-1600 AD, with a peak from 1300-1400' (2008:15). A sediment core from Kau Bay in Halmahera has now been used to reconstruct century-scale climate variability within the Indo-Pacific Warm Pool over the past 3500 years. From this, Langton et al. (2008:795) infer 'diminished ENSO amplitude or frequency, or a departure from El Niño-like conditions during the Medieval Warm Period and distinctive, but steadily decreasing, El Niño activity during and after the little ice age'. 
Based on the previous discussion, the methodology for our study is as follows. Chronology of site occupancy, which is central to our investigation, relies on identifications of dateable imported ceramics at the sites, records of the sites in indigenous and European sources, and Carbon-14 dating for a few sites. We start by reviewing the occupation history of hilltop settlements in South Sulawesi sites including both fortified and unfortified sites. Where traces of fortifications are still visible, these invariably involve stone walls, reflecting the ready availability of stone on hilltops, the improvements to habitation space and gardens from the removal of surface rock, and the difficulties in uphill transportation of other construction materials. We then turn to sites in non-hilltop settings and in particular those with evidence for fortifications rather than the hundreds of non-fortified sites (see Table 7.1 references) whose coverage would be unwieldy. The materials used for fortification are of relevance here both as indicators of the sturdiness and durability of the walls and also access to the introduced technology of brick manufacture. Where the settlement history of these non-hilltop sites evidently included periods with and without functioning fortifications, this is particularly valuable information for identifying the times when a strong defensive capacity and its purpose were most crucial. Times of intensified fortification are set in their historical context both at the scale of local conflict and in terms of peninsula-wide political developments. If the climate-focused models of Field (2008) or Lape and Chao (2008) apply to South Sulawesi, then these 'times of war' should correspond to periods of climatic deterioration. If this expectation fails then an explanation based on factors other than climate should be sought.

\section{Background history to South Sulawesi}

This section provides a brief summary of South Sulawesi's history during the second millennium $\mathrm{AD}$ as background to our coverage of critical sites in the sections that follow.

Political centralisation in South Sulawesi in the form of historical kingdoms (or complex chiefdoms) dates back to the fourteenth century. These kingdoms were based on bilinear descent groups, either a single ruling descent group or a mutually beneficial alliance between two to five descent groups, which traced their origins to a founding apical figure (Bulbeck 1992; Caldwell 1995; Bulbeck and Caldwell 2008; Druce 2009). By the fourteenth century, South Sulawesi had developed trade links with Java, as shown by its four identifiable toponyms recorded in the Desawarnana, Javanese court poem written in 1365 (Robson 1995). The four toponyms (Figure 7.1) are: Selayar, which is an island; Luwuq, ${ }^{4}$ located on the Gulf of Bone but possessing lands in the western Cenrana valley (Bulbeck and Caldwell 2000); and in the Makasar-speaking part of the peninsula, Makassar ${ }^{5}$ and Bantaeng, both of which may refer to a wider area than today's matching toponyms would suggest (Caldwell and Bougas 2004; Reid 1983).

European advances in military technology, introduced to archipelagic Southeast Asia after the Portuguese conquest of Melaka in 1511, increased the scale and intensity of armed conflict in South Sulawesi. Under the joint stewardship of the Goa and Talloq kingdoms, Makassar rose to the status of an emporium by the mid-sixteenth century and over the following decades acquired muskets, brick-making technology, warships and cannons (Reid 1983). Privileged access to firearms enabled the rulers of Goa and Talloq to obtain numerous military victories between the 1540s and 1565, mostly in South Sulawesi but also as far afield as northern Sulawesi and the islands of Sumbawa and Flores. In 1565, as a response to the growing power of Makassar, the Bugis kingdom of Bone forged a defensive alliance with its neighbours, Soppeng

4 Please note our use of ' $\mathrm{q}$ ' to denote a glottal stop in the names of historical kingdoms. This has the advantage of distinguishing them from their modern Indonesian administrative counterparts.

5 Spelled with a double s; the modern name of the city. 
and Wajoq, which restricted Goa-Talloq's late sixteenth-century conquests to other regions of South Sulawesi. In the first half of the seventeenth century, Goa-Talloq successfully subjugated Bone and imposed its authority across South Sulawesi and surrounding islands (Andaya 1981; McWilliam et al. 2012).

Goa-Talloq's seventeenth-century primacy over its Bugis and Makasar neighbours depended on its ability to maintain Makassar as an independent emporium where Moluccan spices could be traded in defiance of the monopoly claimed by the Netherlands East India Company (Vereenigde Oostindische Compagnie, or VOC). This situation held until 1667, when the VOC assembled a naval force with unmatched cannon fire and forged a crucial alliance with Arung Palakka, a minor noble from Bone whom the VOC had previously employed as a mercenary. The VOC warships and Arung Palakka's ground troops besieged and occupied the port city of Makassar, and after a brief resistance destroyed the Makassar empire. Following this victory, the VOC claimed most of the southern coastline by right of conquest and added much of the western coastal plain to its possessions by 1669 (Andaya 1981). Working closely with Bone, the VOC administered Makassar until 1800, when the Netherlands government acquired the now bankrupt company as a crown colony. Following a brief period of British administration in the early nineteenth century, the Netherlands colonial government used Makassar as a base to exert increasing control over South Sulawesi. In 1905-1906, the Dutch completed the process of incorporating the traditional kingdoms of South Sulawesi into the colonial administration in a series of short and occasionally bloody confrontations (De Klerck 1975).

Political developments in the South Sulawesi peninsula from the thirteenth to twentieth centuries were underpinned by large sedentary populations that grew significantly as a result of the expansion and intensification of agriculture (especially wet rice cultivation) after c. 1300 (Macknight 1983; Caldwell 1995; Bulbeck and Caldwell 2008). The growing agricultural wealth of South Sulawesi's kingdoms is reflected in the earliest European accounts of the peninsula. In 1544, a Portuguese visitor to the west coast, Antonio de Paiva, noted that:

The island is rich in all kinds of foodstuffs, of rice and meats ... buffalo ... pig ... chickens ... goat ... all this in abundance. There are great quantities of fish. (Baker 2005:63)

Paiva's glowing description of the agricultural and general economic prosperity of the peninsula is mirrored in seventeenth-century European reports (Gervaise 1701:14-17; Reid 1988:24-25; Andaya 1981:75-76, 90, 265).

\section{Hilltop sites}

If Lape and Chao's (2008) explanatory model for East Timor's fortifications is applicable to South Sulawesi, then the population of South Sulawesi would have retreated to hilltop settlements between $\mathrm{AD} 1150$ and 1700, and settlements in drought-tolerant locations close to droughtsusceptible locations would have erected permanent fortifications as additional protection. According to Lape and Chao (2008:18-19), ENSO-stimulated fortification-building in north coastal East Timor peaked between c. AD 1450 to c. 1650. While settlement locations other than hilltops became progressively abandoned, only those settlements in drought-tolerant locations acquired the additional protection of defensive stone walls. ${ }^{6}$ These additional defences were required to protect the inhabitants from their counterparts on hilltops in locations more severely affected by drought.

6 The naturally defensive location of hilltop settlements is implicit but not clearly stated in Lape and Chao (2008).

\section{terira australis 53}




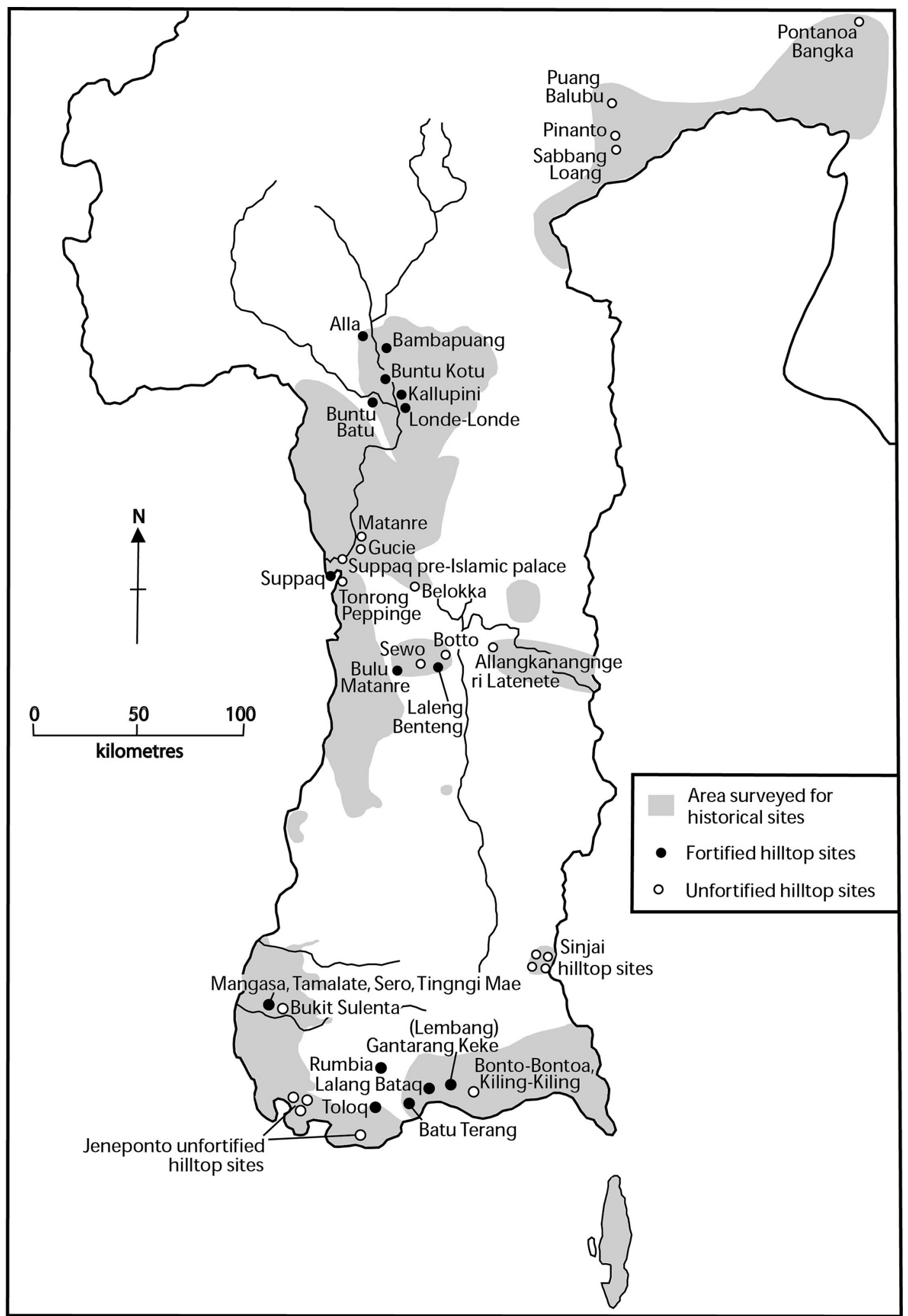

Figure 7.2. South Sulawesi hilltop settlements with and without evidence of fortifications. Source: David Bulbeck. 
Table 7.2 presents the available data on hilltop sites (Figure 7.2) in parts of South Sulawesi with reliable rainfall. The lack of hilltop fortifications in Luwu, Wajo and Sinjai is consistent with the Lape and Chao model as these areas are not prone to drought. However, the presence of both fortified and non-fortified hilltop sites at Goa and Soppeng suggests greater complexity to the construction of fortifications than the Lape and Chao model would allow. For instance, Bulu Matanre in Soppeng protected a mountain pass (Caldwell 1995:397), which may explain why it, and not Sewo, provides evidence for stonewall fortifications. Furthermore, the Suppa and Enrekang hilltop fortifications postdate the period of hypothesised ENSO climatic instability.

Table 7.3 presents the available data on hilltop sites along the more drought-prone southern coast of the South Sulawesi peninsula. The Bantaeng evidence for hilltop fortifications after $\mathrm{AD} 1300$, and their proximity to coeval Jeneponto hilltop (and other) settlements that were generally not fortified, could be regarded as consistent with the Lape and Chao model, inasmuch as Jeneponto is generally more susceptible to drought than is Bantaeng (Caldwell and Bougas 2004). However, there are no accounts, oral or otherwise, of conflict between Bantaeng and its neighbours in the agriculturally marginal land of Jeneponto to the west and Bulukumba to the east. Instead, Bantaeng's fortifications evidently stem from internal conflict during its political integration and/or the need for protection against seaborne attack. In a similar vein, the survival of stone wall defences at Toloq and Rumbia in Jeneponto would appear to stem from their semiautonomous status and consequent responsibility for their own protection (Appendix E).

Table 7.2. Chronologically dated hilltop sites in parts of South Sulawesi with reliable rainfall.

\begin{tabular}{|c|c|c|c|c|}
\hline Site & Approximate dating (AD) & Regency & Fortified? & Reference \\
\hline Uphill Sabbang Loang & $\begin{array}{l}\text { Mid/late 1st millennium, 15th-17th, } \\
\text { 19th-20th Cs }\end{array}$ & Luwu & No & Bulbeck and Caldwell 2000 \\
\hline Pontanoa Bangka & Late 1st millennium, 12th-13th Cs & LuWu & No & Bulbeck 2010 \\
\hline Pinanto hilltop & 14th-16th Cs & Luwu & No & Bulbeck and Caldwell 2000 \\
\hline Puang Balubu & 14th-16th Cs & LuWu & No & Bulbeck and Caldwell 2000 \\
\hline $\begin{array}{l}\text { Allangkanangnge ri } \\
\text { Latanete }\end{array}$ & 13th-17th Cs & Wajo & No & Bulbeck and Caldwell 2008 \\
\hline Bulo-Bulo & 14th-16th Cs & Sinjai & No & Hasanuddin 2011 \\
\hline Lamatti, Tondong & By 16th Cs & Sinjai & No & Hasanuddin 2011 \\
\hline Batu Pake Gojeng & 16th-18th Cs & Sinjai & No & Hasanuddin 2011 \\
\hline Botto & 13th-19th Cs (Dutch early/mid-20th C.) & Soppeng & No & Appendix A \\
\hline $\begin{array}{l}\text { Laleng Benteng } \\
(=\text { 'within fort') }\end{array}$ & 13th C. onwards & Soppeng & $\begin{array}{l}\text { Yes (as of } \\
\text { 16th C.) }\end{array}$ & Appendix A \\
\hline Sewo Tua & 14th-17th Cs & Soppeng & No & Appendix A \\
\hline \begin{tabular}{|l|} 
Bulu Matanre \\
\end{tabular} & 14th-17th Cs & Soppeng & Yes & Appendix A \\
\hline $\begin{array}{l}\text { Mangasa, Kale Goa/ } \\
\text { Tamalate }\end{array}$ & 14th-18th Cs & Goa & $\begin{array}{l}\text { Yes (as of } \\
\text { 16th C.) }\end{array}$ & Bulbeck 1992; Appendix B \\
\hline Bukit Bikuling (Sero) & 14th-18th CS & Goa & Yes (18th C.) & Bulbeck 1992; Appendix B \\
\hline Bukit Sulenta & 17th-18th Cs (graves) & Goa & No & Bulbeck 1992 \\
\hline Tingngi Mae & 18th-19th Cs (graveyard) & Goa & Yes (18th C.) & Bulbeck 1992; Appendix B \\
\hline $\begin{array}{l}\text { Suppaq pre-Islamic } \\
\text { palace }\end{array}$ & $1300-1700$ & Suppa & No & Druce 2009 \\
\hline Gucie & 1300-1700 & \begin{tabular}{|l|} 
Suppa \\
\end{tabular} & No & Druce 2009 \\
\hline Tonrong Peppinge & 14th-16th Cs & Suppa & No & Druce 2009 \\
\hline Belokka & 14th-18th Cs & Sidenreng & No & Druce 2009 \\
\hline Matanre & 14th-19th Cs & Sawitto & No & Druce 2009 \\
\hline
\end{tabular}




\begin{tabular}{|l|l|l|l|l|}
\hline Site & Approximate dating (AD) & Regency & Fortified? & Reference \\
\hline Suppaq fort & 18th-19th Cs & Suppa & Yes & Appendix C \\
\hline Buntu Kotu & 17th-19th Cs & Enrekang & Yes & Appendix D \\
\hline Londe-Londe & 19th-20th Cs & Enrekang & Yes & Makkulasse 1986 \\
\hline Kallupini & 19th-20th Cs & Enrekang & Yes & Makkulasse 1986 \\
\hline Buntu Batu & 19th-20th Cs & Enrekang & Yes & Makkulasse 1986 \\
\hline Bambapuang & 19th-20th Cs & Enrekang & Yes & Makkulasse 1986 \\
\hline Alla & 19th-20th Cs & Enrekang & Yes & Makkulasse 1986 \\
\hline
\end{tabular}

Sources: See references throughout table.

Table 7.3. Chronologically dated hilltop sites in drought-prone parts of South Sulawesi.

\begin{tabular}{|l|l|l|l|l|}
\hline Site & Approximate dating (AD) & Regency & Fortified? & Reference \\
\hline Bonto-Bontoa & 1000 & Bantaeng & No & Bulbeck 2010 \\
\hline Kiling-Kiling & $1000-1200$ & Bantaeng & No & Bulbeck 2010 \\
\hline Lembarang Gantarang Keke & 13th-17th Cs & Bantaeng & Yes & Bougas 1998 \\
\hline Gantarang Keke & 13th C. onwards & Bantaeng & Yes & Bougas 1998 \\
\hline Lalang Bataq (= 'within walls') & Ceremonial site by 15th C. & Bantaeng & Yes (implied) & Bougas 1998 \\
\hline Benteng Batu Terang & 16th-19th Cs & Bantaeng & Yes & Appendix E \\
\hline Karaengloe (Sapanang) & 14th-17th Cs & Jeneponto & No & Caldwell and Bougas 2004 \\
\hline Bangkala Loe & By 17th C. & Jeneponto & No & Caldwell and Bougas 2004 \\
\hline Tanatoa & 14th-16th Cs & Jeneponto & No & Caldwell and Bougas 2004 \\
\hline Banrimanurung hill & By 16th C. & Jeneponto & No & Caldwell and Bougas 2004 \\
\hline Toloq, Rumbia & By 16th C. & Jeneponto & Yes & Caldwell and Bougas 2004 \\
\hline
\end{tabular}

Sources: See references throughout table.

\section{South Sulawesi non-hilltop fortifications}

Lape and Chao (2008:18) described a process of increasing abandonment of East Timor settlements other than those on hilltops between the twelfth and seventeenth centuries. Quite the reverse is apparent for South Sulawesi, where the same period witnessed a proliferation of non-hilltop settlements in the Bone coastal plain (Macknight 1983), Makassar and its hinterland (Bulbeck 1992:463), Luwu (Bulbeck and Caldwell 2000:69, 99) and the Ajattappareng lowlands (Druce 2009:Chapter 5). Fortifications were erected as part of this process (Figure 7.3), which may be consistent with Field's (2008:3) general model for IndoPacific fortifications provided that we find evidence that these fortifications defended densely distributed and temporally predictable resources. To do so, our supplementary material sifts through a considerable body of historical and archaeological evidence. Our summary of the findings is provided in Tables 7.4 to 7.7 . 


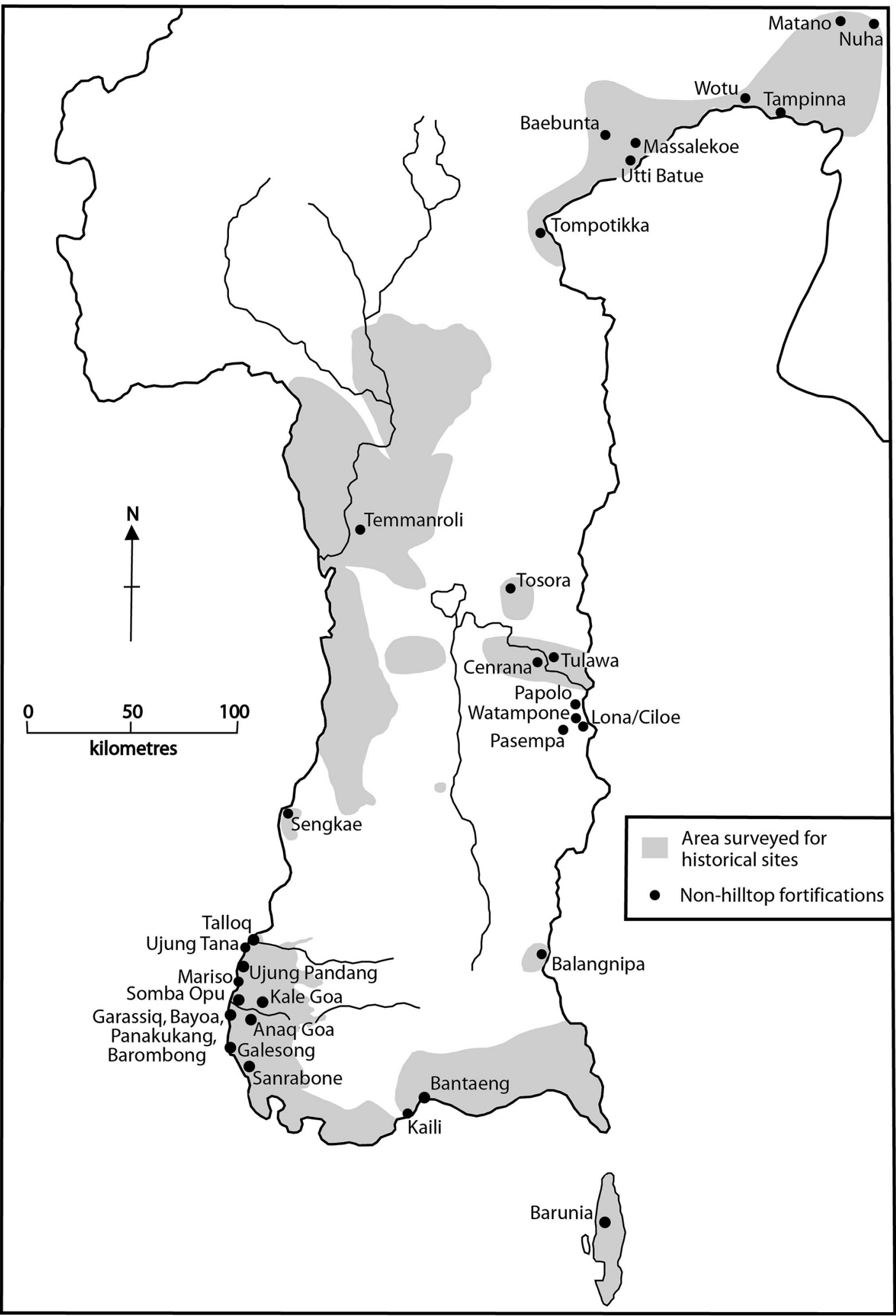

Figure 7.3. South Sulawesi fortifications (excluding fortified hilltop sites).

Source: David Bulbeck. 
Table 7.4. South Sulawesi non-hilltop fortifications in locations near hilltop fortifications.

\begin{tabular}{|l|l|l|l|l|l|}
\hline Fortification & $\begin{array}{l}\text { Form and } \\
\text { dimensions }\end{array}$ & Material & Purpose & $\begin{array}{l}\text { Fortification } \\
\text { period (AD) }\end{array}$ & $\begin{array}{l}\text { Habitation period } \\
\text { at site (AD) }\end{array}$ \\
\hline Temmanroli, Sawitto & Semicircular, 14 ha & Earth (?) & Palace centre defence & By 18th C. & 14th-18th Cs \\
\hline Kale Goa & Pentagonal, 84 ha & $\begin{array}{l}\text { Earth walls } \\
\text { encased with brick }\end{array}$ & Palace centre defence & C. 1540-1778 & 14th-18th Cs \\
\hline $\begin{array}{l}\text { 'Head Quarters No. 1' } \\
\text { (Figure 7.A2), Kale Goa }\end{array}$ & Unknown & Unknown & $\begin{array}{l}\text { Palace perimeter } \\
\text { defence }\end{array}$ & (Late) 18th C. & Unknown \\
\hline $\begin{array}{l}\text { Benteng Malengkeri } \\
\text { (Figure 7.A2), Kale G0a }\end{array}$ & Unknown & Unknown & $\begin{array}{l}\text { Palace perimeter } \\
\text { defence }\end{array}$ & 18th C. & 18th C. \\
\hline $\begin{array}{l}\text { 'No. 3' (Figure 7.A2), } \\
\text { Kale G0a }\end{array}$ & Unknown & Unknown & $\begin{array}{l}\text { Palace perimeter } \\
\text { defence }\end{array}$ & (Late) 18th C. & Unknown \\
\hline $\begin{array}{l}\text { Benteng Bisei } \\
\text { (Figure 7.A2), Kale Goa }\end{array}$ & Unknown & Unknown & $\begin{array}{l}\text { Palace perimeter } \\
\text { defence }\end{array}$ & (Late) 18th C. & Unknown \\
\hline $\begin{array}{l}\text { Benteng Kanonderong } \\
\text { (Figure 7.A2), Kale G0a }\end{array}$ & Unknown & Unknown & $\begin{array}{l}\text { Palace perimeter } \\
\text { defence }\end{array}$ & (Late) 18th C. & Unknown \\
\hline $\begin{array}{l}\text { Benteng Bone in } \\
\text { Makassar (Figure 7.A2) }\end{array}$ & Unknown & $\begin{array}{l}\text { Unknown } \\
\text { (timber?) }\end{array}$ & Military installation & c. 1739-1900 & Unknown \\
\hline $\begin{array}{l}\text { Benteng Kaili, } \\
\text { Bantaeng }\end{array}$ & Unknown & Earth & Unknown & Unknown & Unknown \\
\hline Bantaeng & Unknown & Unknown & Port defence & By 1666 & $\begin{array}{l}\text { 14th/15th C. } \\
\text { 0nwards }\end{array}$ \\
\hline
\end{tabular}

Sources: See Appendices B, C and E.

Table 7.5. Fortifications in Makassar and its hinterland (excluding Kale Goa).

\begin{tabular}{|c|c|c|c|c|c|}
\hline Fortification & \begin{tabular}{|l} 
Form and \\
dimensions
\end{tabular} & Material & Purpose & $\begin{array}{l}\text { Fortification } \\
\text { period (AD) }\end{array}$ & $\begin{array}{l}\text { Habitation period } \\
\text { at site }(\mathrm{AD})\end{array}$ \\
\hline Somba Opu & \begin{tabular}{|l|} 
Quadrangular with \\
southern extension, \\
16-20 ha \\
\end{tabular} & $\begin{array}{l}\text { Mostly walls of solid brick; } \\
\text { some dressed masonry }\end{array}$ & $\begin{array}{l}\text { Port and palace } \\
\text { centre defence }\end{array}$ & c. $1540-1701$ & 16th-18th Cs \\
\hline Talloq & $\begin{array}{l}\text { Parallelogram, } \\
40 \text { ha }\end{array}$ & $\begin{array}{l}\text { Stone walls (some dressed } \\
\text { masonry), and earth walls } \\
\text { encased with brick }\end{array}$ & $\begin{array}{l}\text { Port and palace } \\
\text { centre defence }\end{array}$ & c. $1615-1701$ & 14th C. onwards \\
\hline Garassiq & Triangular, 2.1 ha & Earth and brick & Port defence & 1630s-1701 & 14th C. onwards \\
\hline Bayoa & Triangular, 2.6 ha & Earth and brick & Port defence & 1630s-1670 & 15th C. onwards \\
\hline Panakukang & Quadrangular, 1 ha & $\begin{array}{l}\text { Bricks and coral blocks in } \\
\text { earth wall }\end{array}$ & \begin{tabular}{|l|} 
Port defence \\
\end{tabular} & $1634-1670$ & 15th C. onwards \\
\hline Barombong & Unknown & Earth and brick & Port defence & $1635-1670$ & 17th C. onwards \\
\hline $\begin{array}{l}\text { Somba Opu - } \\
\text { Barombong wall }\end{array}$ & c. 4 km long & Single brick wall & Port defence & 1630s-1670 & 14th C. onwards \\
\hline Ujung Tana & Unknown & Stone & Port defence & 1634-1720s & Unknown \\
\hline Ujung Pandang & $\begin{array}{l}\text { Parallelogram, } \\
1.7 \text { ha } \\
\end{array}$ & Mainly earth? & Port defence & $1634-1667$ & $\begin{array}{l}\text { By } 16 \text { th } \mathrm{C} . \\
\text { onwards }\end{array}$ \\
\hline Mariso & Unknown & Unknown & Port defence & $1634-1670$ & Unknown \\
\hline $\begin{array}{l}\text { Ujung Tana - } \\
\text { Somba Opu wall }\end{array}$ & c. 10 km long & Single brick wall (?) & Port defence & $1634-1670$ & Unknown \\
\hline Anaq Goa & $\begin{array}{l}\text { Parallelogram, } \\
15 \text { ha } \\
\end{array}$ & $\begin{array}{l}\text { Walls of earth with a brick } \\
\text { spine }\end{array}$ & $\begin{array}{l}\text { Military } \\
\text { installation }\end{array}$ & $\begin{array}{l}\text { c. } 1750- \\
1780(?) \\
\end{array}$ & $\begin{array}{l}\text { 15th and 18th Cs } \\
\text { (main phases) }\end{array}$ \\
\hline Sanrabone & Quadrangular, 22 ha & $\begin{array}{l}\text { Earth walls encased with } \\
\text { brick }\end{array}$ & $\begin{array}{l}\text { Harbour and } \\
\text { palace centre } \\
\text { defence }\end{array}$ & $\begin{array}{l}1630 \mathrm{~s}(?) \\
-1781\end{array}$ & 14th C. onwards \\
\hline \begin{tabular}{|l|} 
Galesong \\
\end{tabular} & $\begin{array}{l}\text { c. } 3.5 \mathrm{~km} \text { length } \\
\text { in total }\end{array}$ & $\begin{array}{l}\text { Seven walls and raised } \\
\text { tongues of earth }\end{array}$ & Harbour defence & 1667 & $\begin{array}{l}\text { 1st millennium } \\
\text { onwards }\end{array}$ \\
\hline
\end{tabular}

Sources: See Appendices B, F and G. 
Table 7.6. Other Makasar and Bugis non-hilltop fortifications.

\begin{tabular}{|c|c|c|c|c|c|}
\hline Fortification & Form and dimensions & Material & Purpose & $\begin{array}{l}\text { Fortification } \\
\text { period (AD) }\end{array}$ & $\begin{array}{l}\text { Habitation period } \\
\text { at site }(A D)\end{array}$ \\
\hline Sengkae & $\begin{array}{l}\text { Quadrangular including } \\
\text { river front, } 10 \text { ha }\end{array}$ & Stone foundations & Port defence & c. $1500-1600$ & 15th-17th Cs \\
\hline Balangnipa & Quadrangular, 0.5 ha & Timber & Port defence & 1557-1863 & By 16 th $\mathrm{C}$. \\
\hline Barunia (Selayar) & Quadrangular, 2.7 ha & Stone walls & $\begin{array}{l}\text { Palace centre } \\
\text { defence }\end{array}$ & $\begin{array}{l}\text { Late 18th to } \\
\text { 19th C. }\end{array}$ & $\begin{array}{l}\text { Late 18th to } \\
\text { 19th } C .\end{array}$ \\
\hline Papolo & Unknown & Unknown & Military installation & c. 1565 & Unknown \\
\hline Pasempa & $\begin{array}{l}\text { Three interlocking } \\
\text { walls, } 500 \mathrm{~m} \text { in length }\end{array}$ & Mainly earth & $\begin{array}{l}\text { Military installation } \\
\text { at overland pass }\end{array}$ & c. $1643-1905$ & Unknown \\
\hline Watampone & Quadrangular, 100 ha & $\begin{array}{l}\text { Earth walls with } \\
\text { timber and bamboo }\end{array}$ & $\begin{array}{l}\text { Palace centre } \\
\text { defence }\end{array}$ & $\begin{array}{l}\text { Late } 16 \text { th } C . \\
-1905\end{array}$ & 14th C. onwards \\
\hline $\begin{array}{l}\text { Lona/Ciloe redoubts } \\
\text { (Bajoe) }\end{array}$ & $\begin{array}{l}\text { Three quadrangular } \\
\text { redoubts, } 1 \text { ha in area }\end{array}$ & Unknown & $\begin{array}{l}\text { Port/palace centre } \\
\text { defence }\end{array}$ & c. $1859-1905$ & Unknown \\
\hline $\begin{array}{l}\text { Cenrana ('Istana la } \\
\text { Patauq') }\end{array}$ & $\begin{array}{l}\text { Two quadrangular } \\
\text { enclosures, } 180 \text { ha } \\
\text { in area }\end{array}$ & $\begin{array}{l}\text { Gates of stone } \\
\text { blocks, earth and } \\
\text { uncoursed rubble } \\
\text { walls } \\
\end{array}$ & $\begin{array}{l}\text { Military } \\
\text { installation/palace } \\
\text { centre defence }\end{array}$ & 1671-с. 1760 & c. $1500-1760$ \\
\hline Benteng Tulawa & Unknown & Unknown & Military installation & c. $1745-1760$ & Unknown \\
\hline Tosora & Quadrangular, 100 ha & Earth walls & $\begin{array}{l}\text { Palace centre } \\
\text { defence }\end{array}$ & c. $1639-1840$ & $\begin{array}{l}\text { 16th C. - late } \\
\text { 19th C. }\end{array}$ \\
\hline Utti Batue & $\begin{array}{l}\text { Single wall, } 1.5 \mathrm{~km} \\
\text { long }\end{array}$ & Earth & $\begin{array}{l}\text { Port/palace centre } \\
\text { defence }\end{array}$ & c. $1450-1600$ & c. $1400-1600$ \\
\hline Massalekoe & $\begin{array}{l}\text { Sigmoid wall, } 500 \mathrm{~m} \\
\text { long }\end{array}$ & Earth & \begin{tabular}{|l|}
$\begin{array}{l}\text { Palace centre } \\
\text { defence }\end{array}$ \\
\end{tabular} & c. $1600-1620$ & c. $1600-1620$ \\
\hline Tompotikka (Palopo) & $\begin{array}{l}\text { Parallelogram, } \\
\text { 200-250 ha }\end{array}$ & Earth walls & $\begin{array}{l}\text { Port/palace centre } \\
\text { defence }\end{array}$ & c. $1620-1840$ & 14th C. onwards \\
\hline
\end{tabular}

Source: See Appendices H-M.

Table 7.7. Non-Bugis non-hilltop fortifications in Luwu Regency.

\begin{tabular}{|l|l|l|l|l|l|}
\hline Fortification & Form and dimensions & Material & Purpose & $\begin{array}{l}\text { Fortification } \\
\text { period (AD) }\end{array}$ & $\begin{array}{l}\text { Habitation period } \\
\text { at site (AD) }\end{array}$ \\
\hline Wotu & $\begin{array}{l}\text { Sigmoid wall, } \\
\text { c. } 550 \mathrm{~m} \text { long }\end{array}$ & Earth & Harbour defence & c. 1620-1820 & 15th C. onwards \\
\hline Tampinna & Wall up to $250 \mathrm{~m}$ long & Probably earth & $\begin{array}{l}\text { Maritime traders' } \\
\text { defence }\end{array}$ & c. 1620?-1700 & c. 1400-1700 \\
\hline Baebunta & $\begin{array}{l}\text { Triangular (southern } \\
\text { border formed by } \\
\text { river), } 6 \text { ha }\end{array}$ & Earth & Palace centre defence & c. 1800-1850 & 15th C. onwards \\
\hline Matano & $\begin{array}{l}\text { Eleven curvilinear } \\
\text { segments, } 550 \mathrm{~m} \text { long } \\
\text { in total }\end{array}$ & Earth & $\begin{array}{l}\text { Population } \\
\text { concentration defence }\end{array}$ & 19th C. & 12th C. onwards \\
\hline Nuha & \begin{tabular}{l} 
Single wall \\
\hline
\end{tabular} & Earth & $\begin{array}{l}\text { Population } \\
\text { concentration defence }\end{array}$ & Undocumented & 12th C. onwards \\
\hline
\end{tabular}

Source: See Appendix N. 


\section{Makassar (Goa-Talloq)}

Makassar and its hinterland are the location of the major concentration of indigenous fortifications in South Sulawesi. Tumapaqrisiq Kallona, who ruled the rising agrarian kingdom of Goa from 1511 to 1546 , incorporated the port settlement of Makassar in the early sixteenth century and c. 1540 held onto it against a combined assault from Goa's neighbours (Bulbeck 1992:117119). The Portuguese adventurer Antonio de Paiva visited Makassar in 1544 and 'arrived in the aforesaid port, a large city called Gowa' (Baker 2005:72). In later years, Goa’s partner-kingdom of Talloq, which lay immediately north of Makassar, had at least an equal role in administering Makassar and constructing its impenetrable coastal defences (Reid 1983).

In the sixteenth century, Goa fortified its original, hinterland palace centre of Kale Goa and subsequently erected a fortified palace centre at the coastal location of Somba Opu. In the early seventeenth century, Talloq fortified its coastal palace centre and in the 1630s, in the face of rising military threats from the VOC, a line of forts and a connecting wall were erected between Somba Opu and Talloq (Appendices B and F). Most of Makassar's coastal fortifications were razed in 1670 in accord with the conditions of Goa-Talloq's surrender to the VOC (set out in the Treaty of Bungaya in 1667), but this event by no means marked the end of Goa-Talloq's fortifications. For instance, the 1701 reimposition of the Bungaya treaty required Goa-Talloq to raze the several coastal fortifications it had since rebuilt (Patunru 1983:73). In the late eighteenth century, a popular resistance against the VOC led by Goa was accompanied by the erection of brick fortresses in the Makassar hinterland at Anaq Goa and Goa's original heartland of Kale Goa (Appendix B).

Two further fortification developments south of Makassar were intimately connected to the fortunes of Goa-Talloq. One was Benteng Sanrabone, a brick fortress built before the 1670s and probably during the 1630s. The second was the complex of earthen walls at Galesong which were evidently constructed in their full entirety in 1667 to defend Makassar from the advance of enemy troops from the south (Appendix G).

\section{Other southern South Sulawesi fortifications}

Three further indigenous forts are located in southern Sulawesi. Located to the north of Makassar, Sengkae was the sixteenth-century palace centre (Appendix H) of the kingdom of Siang, which was an early sixteenth-century competitor of Goa prior to its mid-sixteenth-century conquest by Goa (Bulbeck 1992). On the eastern coast of the peninsula, at Sinjai, Balangnipa is remembered by local historians as a wooden fort dated to between the mid-sixteenth and nineteenth centuries (Appendix I); one of the lesser kingdoms instrumental in the Balangnipa fortifications, BuloBulo, was a seventeenth-century ally of Goa-Talloq (Bulbeck 1992). Finally, despite its mark in South Sulawesi's early history, Selayar has failed to yield evidence for fortifications before the eighteenth century. The island's only fortress, Barunia, was probably erected in response to increasing VOC control over Selayar at the time (Appendix J).

\section{Bone and Wajoq}

The Bugis kingdom of Bone originated during the fourteenth century in the vicinity of the present-day regional capital of Watampone (Macknight 1983). Bone played an important part in the political history of South Sulawesi between the sixteenth and early twentieth centuries as reflected in its rich fortification records (Appendix K). Bone provided strong resistance against Goa-Tallog's military campaigns in the sixteenth and seventeenth centuries and established itself as a major powerbroker in Makassar between 1667 and c. 1800. The kingdom maintained its 
status as the most powerful of the South Sulawesi kingdoms throughout the nineteenth century (Reid 1990:103), notwithstanding its expulsion from Makassar in the early nineteenth century, and military assaults on Watampone by the English in 1814, and by the Dutch in 1824, 1859 and 1905 (De Klerck 1975). The first three campaigns saw little in the way of fighting because the Bone forces fled to Pasempa in the highlands. Bone's army was finally defeated by the Dutch at Watampone in 1905 and the kingdom was incorporated into the Netherlands Colonial State.

Wajoq was one of the oldest Bugis kingdoms, and its heartlands lay along the Cenrana valley, east of South Sulawesi's central lowlands. Tosora (Appendix L) was Wajoq's capital by the sixteenth century, but its walls (remains of which are visible today) were reportedly built between 1636 and 1643 (Duli 2010:148). Wajoq's relations with its southern neighbour Bone oscillated between uneasy truce and open warfare. In the late 1730s, Arung Sengkang became ruler of Wajoq and staged a campaign against Bone, culminating in 1739 with the assault by Arung Sengkang, assisted by Karaeng Bontolangkasa, on the Bone and VOC positions in Makassar (Patunru 1983). The VOC countered by driving Arung Sengkang back to Wajoq; a map of Snout's 1740 campaign against Wajoq (de Roever and Brommer 2008:166) shows Wajoq's troops lined up against the VOC/Bone troops along the Cenrana, the latter assisted by a contingent of Tanete troops attacking Wajoq from the west.

\section{Luwu fortifications}

The Bugis kingdom of Luwuq rose to prominence between the fourteenth and sixteenth centuries, based on its control over high-quality iron from the highland regions of Rongkong and Lake Matano. From the fourteenth to seventeenth centuries, Luwuq's capital was located at Malangke on the northwest coast of the Gulf of Bone. In the early seventeenth century, the kingdom appears to have experienced a political and economic crisis and around 1620 moved its palace site to Palopo, today the provincial capital of West Luwu (Bulbeck and Caldwell 2000). ${ }^{7}$ Hereafter, Luwuq functioned as a minor maritime trading power, controlling the traffic in dammar and other forest products from the northern reaches of the Gulf of Bone and the south central Sulawesi highlands until the Dutch occupation in 1905 (Caldwell 1988:196). In accord with the historical and archaeological evidence on the history of Luwuq, we date its fortifications at Malangke to the fifteenth to sixteenth centuries and its earthen fortress at Palopo to the seventeenth to eighteenth centuries (Appendix M).

Luwuq was qualitatively different from the other Bugis kingdoms in that its realm included multiple non-Bugis groups, such as the coastally based Wotu and Bajao sea gypsies, and more hinterland-based groups, such as the Lemolang and Padoe. The relocation of Luwuq's capital to Palopo in the seventeenth century evidently opened the way for local ethnic tensions to spill over, as reflected in the seventeenth-century conflict between the Wotu and Bajao (Bulbeck and Caldwell 2000), and the nineteenth-century construction of defensive fortifications by the Lemolang residents at Baebunta and the Padoe residents at Matano. Another Padoe settlement, Nuha, also has earthen walls, which may also be of nineteenth-century construction even though evidence for their chronology was not collected (Appendix N).

\section{Fortification building materials}

Tables 7.2 to 7.7 demonstrate the preferential use of local building materials for fortifications. Stone was used for building fortifications, not only on hilltops (as observed in our Introduction) but also at Benteng Barunia, located in the Selayar hinterland, and for a minority of coastal fortifications. Away from hilltops, earth was the predominantly used material, except at Makassar

7 Palopo was first occupied at an earlier date, based on the thirteenth- to fourteenth-century ceramic sherds recovered from an area of tumuli within the site (Bulbeck 1996-97:1047). 
and its hinterland, which (along with Sanrabone) have the only fortifications where bricks were used. Bricks are hard-baked earth and so reflect the use of local material in fort construction. Goa-Talloq's capacity to fire bricks, along with the unique use of fine masonry at Benteng Talloq and Somba Opu, including stone blocks sourced to a quarry on the middle Jeneberang River (Bulbeck 1998), underlines the technological advantages Goa-Talloq acquired during the time Makassar operated as an independent emporium (Reid 1983; Bulbeck 1992).

\section{Discussion}

One strength of the South Sulawesi evidence is that, in most cases, a site's occupation history can be distinguished from the period for which there is archaeological and/or historical evidence of fortifications (Tables 7.2-7.7). The distinction makes clear that the building of enduring defences around settlements was not an integral part of initial occupation, and that when it did occur it was usually for a strategic military purpose. Defences such as a protective fence or hedge may well have been erected at sites during their 'non-fortification' period, but the same caveat would also apply to the 'unfortified' East Timor sites reported by Lape and Chao (2008). Were the South Sulawesi fortifications a response to ENSO-related climatic instability, they should have been built between $\mathrm{AD} 1100$ and 1600, with a peak of construction in the fourteenth century (Lape and Chao 2008:15; Langton et al. 2008: Figure 3A). In reality, many sites remained occupied without evidence of fortifications for much or all of this period, with the earliest evidence for fortification postdating 1600 (e.g. Bukit Bikuling, Bantaeng, Temmanroli, Talloq, Garassiq, Galesong, Sanrabone, Palopo, Baebunta, Wotu, Tampinna and Matano). In addition, more fortifications appear to have been in use throughout the period 1650-1850 than at any point up to 1600 (Figure 7.4).

One possibility to be considered is that there was a relationship between fortification building and climatic desiccation, both in East Timor and South Sulawesi, only partially related to ENSO effects. On the world stage, the eleventh to thirteenth centuries were a warm, wet interval (Lamb 1995), despite the onset of more frequent ENSO events (Langton et al. 2008). The peak in ENSO frequency at c. 1300 may have been associated with the transition to the Little Ice Age, whose effects were most marked between the sixteenth and eighteenth centuries (Field 2008:6). ${ }^{8}$ A fourteenth- to eighteenth-century chronology would provide a reasonable match for the South Sulawesi fortifications (Figure 7.4) and also for the East Timor fortifications, with their evidence for a building peak of 1450-1650 and sustained occupation into the early eighteenth century (Lape and Chao 2008:18). In the absence of palaeoenvironmental data from either East Timor (Lape and Chao 2008:15) or South Sulawesi, it may be reasonable to hypothesise an increase in fortifications in both regions at a time of increased rainfall unpredictability associated with the Little Ice Age (cf. Field 2008:4). However, it would be premature to assume that climatic desiccation caused the increase in fortifications without evidence on the scale of conflict in the region (Field 2008:6-7). Furthermore, to understand the constriction history of South Sulawesi fortifications, it is important to recognise the two broad periods involved.

8 While there is little consensus on precisely when it began, or when it ended, it is generally agreed that a period of global cooling set in around 1200, leading to the dreadful European summers of 1315-1317. The climate continued to cool until 1500, when evidence from England, Europe, America and New Zealand points to 'generally rather warmer conditions ... than in the previous century' (Lamb 1995:211). After 1500, temperatures declined again, reaching a nadir in the 1690s with a series of cold, wet summers and bitter winters. During this decade, temperatures in England and on the continent averaged $1.5-2^{\circ} \mathrm{C}$ lower than those of today, shortening the growing season by up to two months. Lamb (1995:212) writes that from the mid-sixteenth century onwards, 'the evidence points to the coldest regime ... at any time since the last major ice age ended ten thousand years or so ago. It is the only time for which evidence from all parts of the world indicates a colder regime than now.' [Authors' italics.] 
Talloq

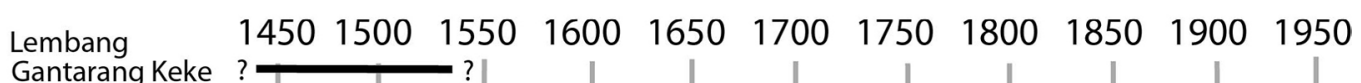

Gantarang Keke

Gantarang Keke

Lalang Bataq

Bulu Matanre

Utti Batue wall

Sengkae fortress

Batu Terang fortress

Laleng Benteng

Kale Goa fortress

Somba Opu fortress

Papolo

Watampone fortress

Balangnipa

Toloq

Rumbia

Massalekoe

Wotu

Tompotikka fortress

Tampinna

Talloq fortress

Garassiq

Bayoa

Panakukang

Barombong

South Macassar wall

Ujung Tana

Ujung Pandang

Mariso

North Macassar wall

Sanrabone fortress

Pasempa

Tosora fortress

Bantaeng

Galesong

Cenrana fortress

Buntu Kotu

Temmanroli

Bone fort (Macassar)

Malengkeri

Other Kale Goa redoubts

Anaq Goa fortress

Benteng Tulawa

Suppaq

Barunia

Benteng Baebunta

Benteng Matano

Lona/Ciloe redoubts

Londe-Londe

Buntu Batu

Kallupini

Bambapuang

$$
\text { Alla }
$$

TOTAL

(5)

(5)

(7)

(12)

(25)

(17)

(17)

(14)

(13)

Figure 7.4. Time chart of South Sulawesi's dated fortifications.

Source: David Bulbeck. 
The first period, up to the 1530s, involved the building of defended hilltop settlements, as well as two early fortifications at coastal trading centres (Utti Batue and Sengkae). This was a building phenomenon broadly similar to that described by Lape and Chao for East Timor, although in South Sulawesi we can ascribe the hilltop fortifications to the political unification of Bantaeng (Appendix E) or, in the case of Bulu Matanre, the defence of a strategic mountain pass. Political unification in South Sulawesi began c. 1300 or slightly earlier in a number of widely separated locations (Bulbeck 1996-97:1049-1050; Bulbeck and Caldwell 2000; Caldwell and Bougas 2004; Bulbeck and Caldwell 2008). Broadly speaking, the fourteenth through fifteenth centuries was a period of internal state-building and consolidation. Warfare in this period occurred mainly within what were to become the historical kingdoms of South Sulawesi. Only in the sixteenth century did armed conflict spill over into open warfare between the kingdoms as they started to vie for wider supremacy, as foreshadowed by the Utti Batue and Sengkae fortifications.

The second period, starting from the 1540s, predominantly involved fortifications at Makassar, or fortifications (such as Benteng Papolo) erected in resistance against whoever controlled Makassar, or fortifications (such as the Cenrana fortress) that functioned as outposts of a powerful faction in Makassar. Control of the port city of Makassar, and its growing trade relations with other areas of the archipelago, was the key to the political integration of South Sulawesi. This was effectively achieved when Goa-Talloq conquered Bone c. 1640, with the result that the late 1660s occupation of Makassar by the alliance between the VOC and Bone led to a changing of the guard rather than political fragmentation. Despite two serious challenges during the eighteenth century and a brief British interregnum, the Dutch retained control of Makassar and effectively prevented any single native kingdom from dominating the peninsula. The story of mid-sixteenth to mid-seventeenth-century fortifications is centred on Makassar and the task of preventing any serious challenge to control of this important harbour. This policy was continued after 1667 by the Dutch through their construction of Fort Rotterdam and the prohibition of indigenous fortifications along the west coast. Only the fortifications at Luwu inland from the Gulf of Bone appear to have been built according to a rhythm other than control over/defence against Makassar (Appendices $\mathrm{M}$ and $\mathrm{N}$ ). Unlike the agrarian kingdoms to its south, Luwuq's economy was based on its ability to maintain order among the settlements that bartered iron and other hinterland produce at Luwuq's port-capitals of Malangke up to c. 1600 (Bulbeck and Caldwell 2000) and Palopo between the seventeenth and early nineteenth centuries (van Braam Morris 1889).

The three main purposes of sixteenth-century and later fortifications were port defence, palace centre defence and military installations (Tables 7.4-7.7). The purposes of port and palace centre defence were often combined when maritime trade was critical to a kingdom's economy. Control over fertile wet rice land was also an important stimulus for the fortification programs at Makassar (affording control over the Maros and southwest coastal rice lands), Watampone, Wajoq and Temmanroli. The combination of archipelagic trade and control over rice-growing lands has been recognised as central to the historical process of political unification in South Sulawesi (Bulbeck and Caldwell 2008). In a development that does not appear to have transpired in East Timor, fortification programs shifted (as it were) from the natural defensive location of hilltops to prime economic locations for maritime trade and wet rice production (locations with concentrated and temporally predictable resources, in Field's (2008:3) terms). Only when the Dutch advanced on Massenrempulu to complete their colonisation of South Sulawesi do we find a return to a predominance of hilltop fortifications.

The fourteenth to sixteenth centuries appear to have been a period of largely uninterrupted economic and demographic growth in South Sulawesi, and the onset of durable fortifications should be viewed in this context rather than as a response to climatic desiccation. Nonetheless, 
we leave open the possibility of a relationship between South Sulawesi's mid-seventeenth-century political integration and the effects of the peak of the Little Ice Age. Writing of the widespread economic downturn in Southeast Asia after 1630, Reid (1993:291) makes the statement that "The most truly global explanation of the "general crisis" is ... the gradual decline in temperatures during the seventeenth century'. A part of this 'general crisis' may possibly have been due to specific ENSO effects: Quinn et al. (1978) have demonstrated a correlation between El Niño events in Java, while tree rings from the teak forests of east central Java show the period 15981679 to be the worst substantial period for rainfall between 1514 and 1929 (Reid 1993:291). While the effects of the Little Ice Age upon the humid tropics remain unclear, they probably include a greater variability of short-term changes in the weather. Lamb (1995:219-220) points out that it is precisely at such periods of global cooling that climatic conditions are most variable. Combined with increased dryness, such conditions would result in less predictable yields and more frequent harvest failures. By the mid-seventeenth century, populations in South Sulawesi may have been close to carrying capacity despite the widespread felling of forests and their replacement by agricultural lands (especially wet rice fields). The peninsula-wide scale of conflict in South Sulawesi after the early seventeenth century might possibly have been exacerbated by such a crisis, as reduced rainfall and smaller harvests met rising populations and hungry stomachs. This possibility remains to be examined.

\section{Conclusion}

The proximate cause for the major period of fortification construction and use in South Sulawesi between the mid-sixteenth and early twentieth centuries was the struggle for political supremacy across the peninsula. European weaponry and other technological advances played a major role in escalating the scale of warfare in the South Sulawesi peninsula. The virtual monopoly that the west coast alliance of Goa and Talloq enjoyed over European firepower between the mid-sixteenth and mid-seventeenth centuries enabled Makassar to rule increasingly large swathes of the peninsula. The partnership between the VOC and the east coast kingdom of Bone was the major political force in the peninsula between the late seventeenth and late eighteenth centuries, despite several challenges to the partnership's supremacy. Between the early nineteenth and early twentieth centuries the European administration in Makassar (starting with the British administration of 1811-1816) exerted increasing colonial control over South Sulawesi. For climatic unpredictability to have been the causal factor for South Sulawesi's increase in fortifications, it must also have been the cause for an increasing role in European military technology in South Sulawesi-a speculative proposition for which no evidence has been found. Perhaps climatic instability associated with the Little Ice Age, associated with reduced-not enhanced-ENSO activity, was a dominant cause for the increase in fortifications in the agriculturally marginal belt of north coastal East Timor. But on present evidence this was not the case in South Sulawesi.

\section{Acknowledgements}

We are grateful to Campbell Macknight for access to texts and illustrative documents in his possession, as well as advice and comments on drafts of this paper. Budianto Hakim of Balai Arkeologi Makassar accompanied David Bulbeck during the survey of the Watampone fortifications in December 2010 and Bantaeng fortifications in October 2011. The detailed comments of two anonymous referees are gratefully acknowledged. 


\section{References}

Andaya, L.Y. 1981. The heritage of Arung Palakka: A history of South Sulawesi (Celebes) in the seventeenth century. Verhandelingen van het Koninklijk Instituut voor Taal-, Land- en Volkenkunde 91. Martinus Nijhoff, The Hague. doi.org/10.26530/oapen_613368.

Baker, B. 2005. South Sulawesi in 1544: A Portuguese letter. Review of Indonesian and Malaysian Affairs 39:61-85.

Bigalke, T.W. 2005. Tana Toraja: A social history of an Indonesian people. Singapore University Press, Singapore.

Bougas, W.A. 1998. Bantayan: An early Makassarese kingdom. Archipel 55:83-123. doi.org/10.3406/ arch.1998.3444.

Boxer, C.R. 1967. Francisco Viera de Figueiredo: A Portuguese merchant-adventurer in South East Asia, 1624-1667. Martinus Nijhoff, The Hague. doi.org/10.26530/oapen_613438.

Budiarta, H. 2007. Taking and returning objects in a colonial context: Tracing the collections acquired during the Bone-Gowa military expeditions. In P. ter Keurs (ed.), Colonial collections revisited, pp. 123-143. CNWS Publications, Leiden.

Bulbeck, D. 1996-97. The Bronze-Iron Age of South Sulawesi, Indonesia: Mortuary traditions, metallurgy and trade. In F.D. Bulbeck and N. Barnard (eds), Ancient Chinese and Southeast Asian Bronze Age cultures. Volume II, pp. 1007-1076. Southern Materials Center, Taipei.

Bulbeck, D. 1998. The construction history and significance of the Makassar fortifications. In K. Robinson and M. Paeni (eds), Living through histories: Culture, history and social life in South Sulawesi, pp. 67-106. The Australian National University, Canberra.

Bulbeck, D. 2010. Uneven development in southwest Sulawesi, Indonesia during the Early Metal Phase. In B. Bellina, E.A. Bacus, T.O. Pryce and J. Wisseman Christie (eds), 50 years of archaeology in Southeast Asia: Essays in honour of Ian Glover, pp. 152-169. Bangkok: River Books.

Bulbeck, D. and I. Caldwell 2000. Land of iron: The historical archaeology of Luwu and the Cenrana Valley. Results of the origin of complex society in South Sulawesi Project (OXIS). Centre for South-East Asian Studies, University of Hull, Hull.

Bulbeck, D. and I. Caldwell 2008. Oryza sativa and the origins of kingdoms in South Sulawesi, Indonesia: Evidence from rice husk phytoliths. Indonesia and the Malay World 36:1-20. doi.org/10.1080/136398 10802016117.

Bulbeck, D. and B. Prasetyo 1998. Survey of pre-Islamic historical sites in Luwu, South Sulawesi. Walennae 1:29-42.

Bulbeck, D. and B. Prasetyo 1999. The origins of complex society in South Sulawesi (OXIS). Unpublished final report to Lembaga Ilmu Pengetahuan Indonesia.

Bulbeck, D., D. Bowdery, J. Field and B. Prasetyo 2007. The palace centre of sago city: Utti Batue site, Luwu, South Sulawesi, Indonesia. In M. Lillie and S. Ellis (eds), Wetland archaeology and environments: Regional issues, global perspectives, pp. 119-141. Oxbow Books, Oxford.

Bulbeck, F.D. 1992. A tale of two kingdoms: The historical archaeology of Gowa and Tallok, South Sulawesi, Indonesia. Unpublished PhD thesis. The Australian National University, Canberra.

Caldwell, I. 1988. South Sulawesi A.D. 1300-1600: Ten Bugis texts. Unpublished PhD thesis. The Australian National University, Canberra.

Caldwell, I. 1995. Power, state and society among the pre-Islamic Bugis. Bijdragen tot de Taal-, Land-en Volkenkunde 151:396-421. doi.org/10.1163/22134379-90003038. 
Caldwell, I. and W.A. Bougas 2004. The early history of Binamu and Bangkala. Bijdragen tot de Taal-, Land-en Volkenkunde 160:456-510. doi.org/10.1163/22134379-90003720.

CIA World Factbook. www.cia.gov/library/publications/resources/the-world-factbook/index.html. Accessed 23 March 2020.

Cummings, W.P. (ed. and trans.) 2007. A chain of kings: The Makassarese chronicles of Gowa and Talloq. Koninklijk Instituut voor Taal, Land- en Volkenkunde, Leiden. doi.org/10.26530/oapen_376974.

Cummings, W. 2011. The Makassar annals. Koninklijk Instituut voor Taal, Land- en Volkenkunde, Leiden.

De Klerck, E.S. 1975. History of the Netherlands East Indies. Volume II. B.M. Israël NV, Amsterdam.

de Roever, A. and B. Brommer 2008. Indische Archipel en Oceanie. Groote Atlas van de Verenigte OostIndische Compagnie. Volume III. Atlas Maior, Voerburg.

Druce, S.C. 2009. The lands west of the lakes: A history of the Ajattappareng kingdoms of South Sulawesi 1200 to 1600 CE. Koninklijk Instituut voor Taal, Land- en Volkenkunde, Leiden. doi.org/10.26530/ oapen_381395.

Duli, A. 2010. Peranan Tosora sebagai pusat pemerintahan kerajaan Wajo abad XVI - XIX. Walennae 12:143-158.

Fadillah, M.A. 1999. Survei dan ekskavasi Bonto-Bontoa, Bantaeng Timur: investigasi awal. Walennae 3:13-38.

Fadillah, M.A. 2000. Arkeologi dan Sejarah kuna Wotu: Catatan survei dan eksksavasi. In M.A. Fadillah and I. Sumantri (eds), Kedatuan Luwu: Perspektif Arkeologi, Sejarah dan Antropologi, pp. 159-195. Lembaga Penerbitan Universitas Hasanuddin, Makassar.

Fadillah, M.A. and M.I. Mahmud 2000. Kerajaan Siang Kuna: Sumber Tutur, Teks dan Tapak Arkeologi. Balai Arkeologi Makassar, Makassar.

Field, J.S. 2008. Explaining fortifications in Indo-Pacific prehistory. Archaeology in Oceania 43:1-10. doi.org/10.1002/j.1834-4453.2008.tb00025.x.

Gervaise, N. 1701. An historical description of the kingdom of Macassar in the East-Indies. English translation of the original 1688 publication in French. Thomas Leigh and D. Midwinter, London.

Grimes, C.E. and B.D. Grimes 1987. Languages of South Sulawesi. Pacific Linguistic Series D-No. 78. The Australian National University, Canberra.

Hadimulyono, dkk. 1985. Studi kelayakan bekas ibu kota Kerajaan Wajo (abad XVII) di Tosora, Kabupaten Wajo Sulawesi Selatan. Unpublished. SPSP Sulselra, Ujung Pandang.

Hasanuddin 2011. Megalithic sites in the district of Sinjai, South Sulawesi, Indonesia. Bulletin of the Indo-Pacific Prehistory Association 31:76-84. doi.org/10.7152/bippa.v31i0.10660.

Heersink, C.G. 1994. Selayar and the green gold: The development of the coconut trade on an Indonesian island (1820-1950). Journal of Southeast Asian Studies 25:47-69. doi.org/10.1017/ s0022463400006676.

Kallupa, B. 1984. Taman Purbakala Batu Pake Gojeng, Kabupaten Sinjai, Sulawesi Selatan. Proyek Pemuguran dan Pemeliharaan Peninggalan Sejarah dan Purbakala Sulawesi Selatan, Makassar.

Kallupa, B. 1985. Study Kelayakan Bekas Ibu Kota Kerajaan Wajo (Abad VXII) di Tosora Kab. Wajo Sulawesi Selatan. Proyek Pemugaraan dan Pemeliharaan Peninggalan Sejarah dan Purbakala Sulawesi Selatan, Makassar.

Kallupa, B., D. Bulbeck, I. Caldwell, I. Sumantri and K. Demmanari 1989. Survey Pusat Kerajaan Soppeng 1100-1986. Privately published, Canberra. ISBN 073-1690-78-8.

Lamb, H.H. 1995. Climate history and the modern world. 2nd edition. Routledge, London. 
Langton, S.J., B.K. Linsley, R.S. Robinson, Y. Rosenthal, D.W. Oppo, T.I. Eglinton, S.S. Howe, Y.S. Djajadihardja and F. Syamsudin 2008. 3500 yr record of centennial-scale climate variability from the Western Pacific Warm Pool. Geology 36(10):795-798. doi.org/10.1130/g24926a.1.

Lape, P.V. and C.-Y. Chao 2008. Fortification as a human response to late Holocene climate change in East Timor. Archaeology in Oceania 43(1):11-21. doi.org/10.1002/j.1834-4453.2008.tb00026.x.

Ligtvoet, A. 1880. Transcriptie van het dagboek der vorsten van Gowa en Tello. Bijdragen tot de Taal-, Land-en Volkenkunde 28(4):1-259. doi.org/10.1163/22134379-90000513.

Macknight, C.C. 1983. The rise of agriculture in South Sulawesi before 1600. Review of Indonesian and Malaysian Affairs 17:92-116.

Macknight, C.C. 1993. The early history of South Sulawesi: Some recent advances. Centre of Southeast Asian Studies Working Papers 81. Monash University, Clayton.

Mahmud, M.I. 1993. Struktur Kota Palopo Abad XVII - XIX Masehi: Studi Arkeologi tentang Pemahaman Eksperiensial dan Cita-Pikiran. Sarjana thesis. Hasanuddin University, Makassar.

Mahmud, M.I. 2000. Pemukiman kuna Cenrana, Bone: Beberapa aspek sejarah sosial Bugis. Walennae 5:43-64.

Makkulasse 1986. Laporan Pengumpulan Data 'Peninggalan Sejarah dan Purbakala' Kabupaten Enrekang. Suaka Peninggalan Sejarah dan Purbakala Sulawesi Selatan, Makassar.

Masdoeki 1984. Laporan Pengumpulan Data Peninggalan Sejarah dan Purbakala di Kabupaten Barru. Suaka Peninggalan Sejarah dan Purbakala Sulawesi Selatan, Makassar.

Masdoeki 1985. Laporan Pengumpulan Data Peninggalan Sejarah dan Purbakala di Kabupaten Takalar. Suaka Peninggalan Sejarah dan Purbakala Sulawesi Selatan, Makassar.

McWilliam, A., D. Bulbeck, S. Brockwell and S. O'Connor 2012. The cultural legacy of Makassar stone in East Timor. The Asia Pacific Journal of Anthropology 13(3):262-279. doi.org/10.1080/14442213. 2012.674054 .

Monk, K.A., Y. de Fretes and G. Reksodiharjo-Lilley 1997. The ecology of Nusatenggara and Maluku. Periplus, Hong Kong.

Muhaeminah 2009. Benteng kolonial Belanda di Balangnipa Kabupaten Sinjai. Walennae 11:51-64.

Muhaeminah 2010. Situs Bacukiki di kota Parepare peluang pemanfaatan sebagai obyek wisata budaya. Walennae 12:177-188.

Muhaeminah and I. Mahmud 2009. Pusat peradaban abad XV-XVIII kerajaan Buki Selayar Sulawesi Selatan. Walennae 11:139-160.

Mundy, R. 1848. Narrative of events in Borneo and Celebes, down to the cccupation of Labuan: From the journals of James Brooke, Esq., Rajah of Sarawak, and Governor of Labuan. Together with a narrative of the operations of H.M.S. Iris. Volume 1. John Murray, London.

Muttalib, M.A. 1978. Petunjuk Singkat tentang Kompleks Makam Kuno Raja-Raja Lamuru. Kantor Suaka Sejarah dan Purbakala, Wilayah Propinsi Sulawesi Selatan, Makassar.

Muttalib, M.A. 1980. Naskah Studi Kelayakan. Makam La Tenri Ruwa (Raja Bone ke XI), Bantaeng, Sulawesi Selatan. Proyek Pemuguran dan Pemeliharaan Peninggalan Sejarah dan Purbakala Sulawesi Selatan, Makassar.

Muttalib, M.A. 1983. Laporan Pengumpulan Data Peninggalan Sejarah dan Purbakala di Kabupaten Bulukumba. Proyek Pemuguran dan Pemeliharaan Peninggalan Sejarah dan Purbakala Sulawesi Selatan, Makassar.

Nayati, W. 2000. Laporan Survei Arkeologi Daerah Kabupaten Bantaeng, Sulawesi Selatan. Unpublished report. Makassar. 
Nur, M. and B. Hakim 2010. Telaah awal tembikar Wajo. Walennae 12:189-194.

OXIS Group 2020. Pre-Islamic South Sulawesi. oxis.org. Accessed 23 March 2020.

Patunru, D.A.R. 1983. Sejarah Gowa. Yayasan Kebudayaan Sulawesi Selatan di Makassar (Ujung Pandang), Makassar.

Pelras, C. 1977. Les premières données occidentales concernant Célèbes-sud. Bijdragen tot de Taal-, Landen Volkenkunde 133:227-260.

Perelaer, M.T.H. 1872. De Bonische Expeditiën Krijggebeurtenissen op Celebes in 1859 et 1860 volgens officiëele Bronnen Bewerkt. Gualth Kolff, Leiden.

Quinn, W.H., D.O. Zopf, K.S. Short and R.T.W. Kuo Yang 1978. Historical trends and statistics of the Southern Oscillation, El Nińo, and Indonesian drought. Fishery Bulletin 76:663-678.

Reid, A. 1983. The rise of Makassar. Review of Indonesian and Malaysian Affairs 17:117-160.

Reid, A. 1988. The lands below the winds. Southeast Asia in the age of commerce 1450-1680. Volume 1. Yale University Press, New Haven.

Reid, A. 1990. Bone and Soppeng: Vanished Bugis kingdoms. In T.A. Volkman and I. Caldwell (eds), Sulawesi: The Celebes, pp. 102-105. Periplus, Singapore.

Reid, A. 1993. Expansion and crisis. Southeast Asia in the age of commerce 1450-1680. Volume 2. Yale University Press, New Haven.

Robson, S. (trans.) 1995. Desawarnana (Nagarakrtagama) by Mpu Prapanca. KITLV Press, Leiden.

Roessingh, M.P.H. 1986. A pretender to Gowa's throne: The war of Batara Gowa I. Sangkilang in south west Celebes, 1776-c. 1790. In R. Russ and G.D. Winius (eds), All of one company: The VOC in biographical perspective, pp. 151-177. Hes Uitgevers, Utrecht.

Schilder, G., J. Moerman, F. Ormeling, P. van den Brink and H. Ferwerda 2006. Atlas Isaak de Graf. Groote Atlas van de Verenigte Oost-Indische Compagnie. Volume I. Atlas Maior, Voerburg.

Somba, N. 2009. Jejak-jejak arkeologis di kaki Gunung Bambapuang Kabupaten Enrekang, Sulawesi Selatan. Walennae 11:107-124.

Somba, N. 2010. Ciri budaya Austronesia di kawasan Enrekang Sulawesi Selatan. Walennae 12:1-10.

Stavorinus, J.S. 1798. Voyages to the East Indies. Volume 2. Translated into English by S.H. Wilcocke. G.G. Robinson and J. Robinson. Dawsons of Pall Mall, London.

Suaka Peninggalan Sejarah dan Purbakala Sulawesi Selatan 1984. Laporan Pengumpulan Data Peninggalan Sejarah dan Purbakala di Kabupaten Bantaeng. Makassar.

Sudarti Surbakti, R. Lukito Praptoprijoko, Satwiko Darmesto 2000. Indonesia's 2000 population census: A recent national statistics activity. BPS Statistics Indonesia, Bangkok.

van Braam Moris, D.F. 1889. Het landschap Loewoe. Tijdschrift van het Bataviaasch Genootschap van Kunsten en Wetenschappen 32:497-555.

van Rijneveld, J.C. 1840. Celebes, of Veldtogt der Nederlanders op het Eiland Celebes in de Jaren 1824 en 1825. Broese, Breda.

Wallis, H. (ed.) 1965. Carteret's voyage round the world 1766-1769. Volume II. Hakluyt Society, Cambridge University Press, Cambridge, Massachusetts. doi.org/10.4324/9781315570914.

Wibisono, C.S. 1985. Sebaran situs kubur sebagai studi awal pola pemukiman di Pulau Selayar. Rapat Evaluasi Hasil Penelitian Arkeologi II, pp. 370-383. Pusat Penelitian Arkeologi Nasional, Jakarta. 


\section{Appendices}

\section{Appendix A: Hilltop sites in the kingdom of Soppeng}

Table 7.2 identifies as hilltop sites the two prominent peaks of Botto and Laleng Benteng in the current kabupaten capital of Watansoppeng, but in fact Watansoppeng itself could be considered a hilltop site. The township sits on a plateau perched above the confluence of the Soppeng and Masewali rivers, leaving only its western flank vulnerable to attack across flat terrain. There is no evidence that enemy troops ever entered Watansoppeng, although Soppeng did concede its vassals along the lower Walennae to Goa in the mid-sixteenth century (cf. Caldwell 1995: Figure 2; Cummings 2007:33). The construction of the stonewall defences recorded at Soppeng's traditional palace, Laleng Benteng, is dated to around the time of Soppeng's unification (Kallupa et al. 1989).

Sewo and Bulu Matanre were two hilltop settlements in the mountains with heavy rainfall immediately to the west of Watansoppeng. Both were first occupied in the fourteenth century and abandoned around 1700 (Kallupa et al. 1989). Sewo sits on a defensible hill, while Bulu Matanre was a fortified mountain settlement dating back to the early fifteenth century (Caldwell 1995:397). Its low stone walls surrounding garden beds recorded during the site survey (Kallupa et al. 1989:49-50) may have been built from the remains of the settlement's stone walls.

\section{Appendix B: Kale Goa and Anaq Goa}

By the fourteenth century the emergent kingdom of Goa was based at Kale Goa, a settlement focused on two hillocks overlooking the Jeneberang River, $6 \mathrm{~km}$ from its mouth (Bulbeck 1992:219-220). Kale Goàs early fortifications included earth walls erected during Tumapaqrisiq Kallona's reign (1511-1546), brick walls during the reign of his successor Tunipalangnga (1546-1565) and refurbished brick walls during the reign of Sultan Alauddin (1593-1639). Bulbeck (1992:216) attempted to explain the fortress remains at Kale Goa in terms of these three building episodes, but we now suspect that at least some of the fortifications, in particular the $8 \mathrm{~m}$ thick walls facing the Jeneberang (Figure 7.A1a), are of later construction (Figure 7.A1b). We note that Goa had been forced by the VOC to demolish Kale Goa's walls in 1676, having rebuilt them using the loose bricks of the demolished fortress (Andaya 1981:174). ${ }^{9}$ As documented below, Kale Goa was a functioning fortress in the late 1700s, having presumably been restored earlier in the century.

The c. 1776 Dutch sketch of 'Goa' in de Roever and Brommer (2008:195) can be identified as Kale Goa from toponymic and physiographic matches (Figure 7.A2):

- Data to the immediate north of the fortress

- Bisei at the northeast of the fortress

- Bonsong/Lonjo Boko at the east of the fortress

- Sero at/on a hill to the immediate east of the fortress

- Pandang at the southeast of the fortress

- Tinggi Mae on a hill to the immediate southeast of the fortress

- Mangasa at the south of the fortress

- Taeng across the river to the immediate southwest of the fortress

- 'Grave of the King of Goa', which could correspond to either the early eighteenth-century Arung Palakka cemetery or the seventeenth/eighteenth-century royal Goa graves at the east.

9 Andaya calls them 'red stones', a literal translation of batu merah, a local synonym for batu bata (bricks). 


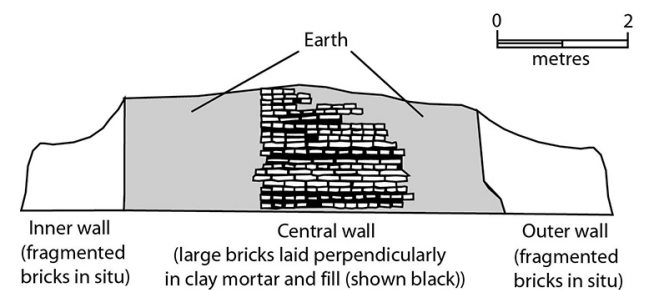

(a) Kale Goa section - three wall lines

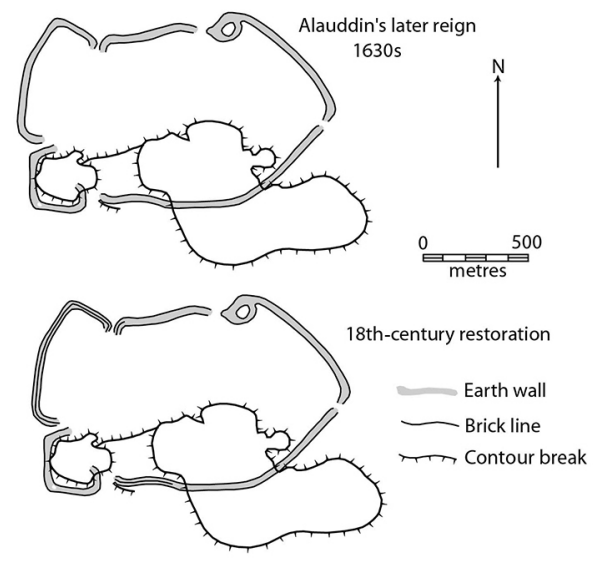

(b) Revised Kale Goa construction sequence

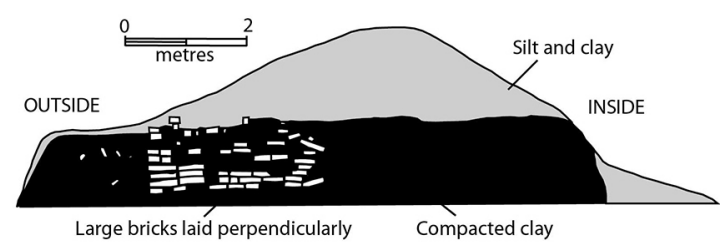

(c) Anaq Goa section

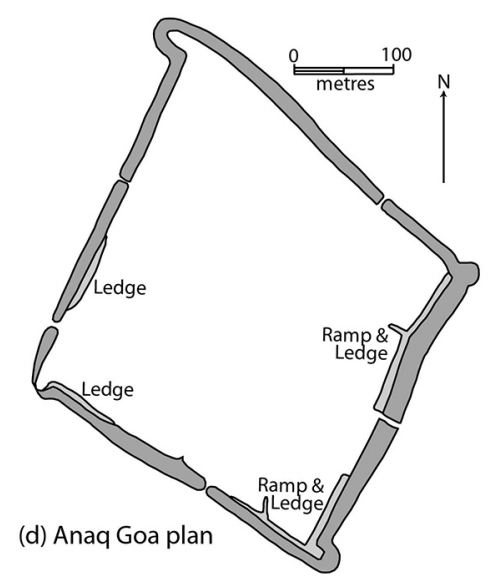

Figure 7.A1. Cross-section and plans for Benteng Kale Goa and Anaq Goa.

Source: David Bulbeck (after Bulbeck 1992).

We cannot make sense of all of the Dutch toponyms but draw attention to important eighteenth-century associations: Goa erected a royal residence at Sero in 1703; Malengkeri was the 1727-1735 residence of the Goa king; Tinggi Mae was the place where the Goa king prayed for rain in 1736; and Mangasa was the place where the Talloq king went fully armed in 1748 (see Cummings 2011:145, 223, 245, 248, 267). In addition, the palace (benteng) of Bone is shown as situated close to Kale Goa. This may indicate the approximate location of Bone's military headquarters in Makassar after its earlier headquarters at Bonto Alaq were burnt down during Wajoq's 1739 assault on Makassar (Patunru 1983:79).

The reason for the sudden Dutch interest in Kale Goa was the threat posed by I Sangkilang, a Makasar man of obscure origins, who appeared in 1776 claiming to be the king of Goa whom the Dutch had expelled from South Sulawesi a decade earlier. I Sangkilang led a popular uprising against Dutch positions south of Makassar and, in 1777, occupied Maros, Talloq and, finally, Goa, where he was installed as ruler. The Bugis toponyms at the north of Kale Goa and the Talloq contingent at Kale Goa's eastern flank, c. 1776 Dutch sketch of 'Goa' (Figure 7.A2), evidently represent Goa's allies positioned in an attempt to defend the Goa citadel. ${ }^{10}$ In the end, the VOC proved victorious, razing Kale Goa's walls during its assault in 1778 and driving I Sangkilang into the mountains. The VOC reinstated Sultan Zainuddin as Goa's ruler, but in 1781 forbade Goa from rebuilding Kale Goa's walls (Patunru 1983:85-89; Roessingh 1986).

10 Datu Baringang was the Bone war commander who attacked I Sangkilang in Maros in 1777 (Patunru 1983:86). The GoaTalloq royal diary notes the establishment of peaceful relations between Tanete (Agannionjoq), Soppeng and Bone in 1750 (Ligtvoet 1880:220, 229). 

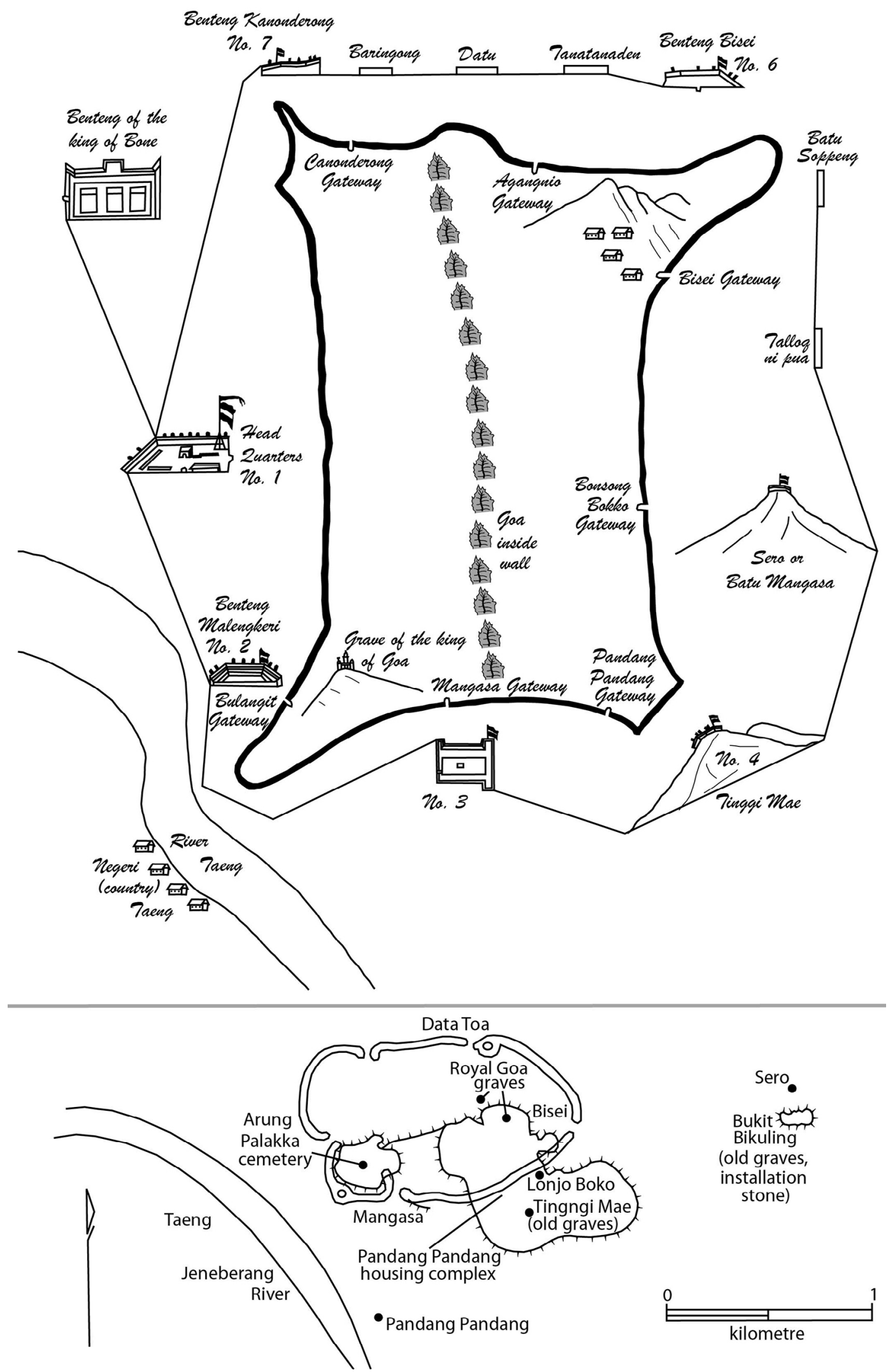

Figure 7.A2. 'Dutch sketch of Goa c. 1776' (above) compared to relevant data from Bulbeck's (1992) survey of Kale Goa (below).

Source: David Bulbeck. 
Benteng Anaq Goa was interpreted by Bulbeck (1992:262-264) as a mid-sixteenth-century fortress built by Tunipalangnga for his son, Karaeng Anaq Goa, who died in childhood. One of Bulbeck's reasons was that there is no other pre-1700 reference to Anaq Goa; a second was that the inner spine of large bricks within its $8 \mathrm{~m}$ thick walls resembled the inner spine of large bricks along Kale Goa's western wall (Figure 7.A1c). However, the authors have found Anaq Goa depicted on a 1752 map of southern South Sulawesi (de Roever and Brommer 2008:164-165) and now believe that the structural resemblance of the walls could be explained by an eighteenthcentury construction date for both fortifications, for reasons explained below.

Ceramic evidence points to more substantial occupation at Anaq Goa between 1650 and 1800 than between 1500 and 1650 (Bulbeck 1992: Figure 8.3). This cautions against dating the fortress's occupation to a time before 1650 . In addition, the virtually pristine condition of the fortress suggests a relatively recent chronology, as well as implying that the site has been spared military engagement. The fact that 1751 was the last year for which entries appear in the 'Makassar Annals' (Cummings 2011) might explain its lack of reference to Anaq Goa were it constructed after this year. On balance, acknowledging the ambiguities in the evidence, we prefer a mid-eighteenth-century dating for Anaq Goa's construction (Figure 7.A1d) and surmise that it was never used as a military installation.

\section{Appendix C: Ajattappareng fortifications}

Ajattappareng is the name for the confederation of Bugis kingdoms of Sidenreng, Rappang, Sawitto, Alitta and Suppaq, which jointly ruled the fertile wet rice lands between the mouth of the Saddang and South Sulawesi's central lowlands. Druce (2009: Appendix B) surveyed six hilltop settlements, only one of which was fortified. The last is a hilltop of around 1.4 hectares overlooking the eighteenth-century to modern-day port of Suppaq, where Druce (2009:129-131, Figure B.18) recorded nineteenth-century sherdage. This is clearly the fort at Suppaq sketched by van Rijneveld (1840: Plate 2), which forms part of his account of the 1824 Dutch attack on Suppaq, following three unsuccessful assaults on Suppaq by the English in 1814 (De Klerck 1975:146). The construction of the fort was thus evidently a response to European colonial expansion.

Druce (2009:125-126) mapped the outline of a fortress that reportedly extended over 14 hectares at Temmanroli. This fortress served as the palace centre of the early rulers of Sawitto in the fourteenth or fifteenth century. While the date of construction of the fortress is unknown, it includes the grave of a major eighteenth-century ruler, and would appear to have been functional at the time Sawitto relocated its palace centre to Lalle Lama in the nineteenth century.

\section{Appendix D: Enrekang (Massenrempulu) fortifications}

The Massenrempulu fortifications reveal a dichotomy between Benteng Buntu Kotu on the one hand, and Benteng Londe-Londe, Kallupini, Buntu Batu, Bambapuang and Alla on the other. Benteng Buntu Kotu has abundant habitation evidence (Somba 2009), but no record of involvement in the early twentieth-century conflict between the Dutch and the Massenrempulu polities. The remaining five fortresses were used in the Massenrempulu resistance against the Dutch but show minimal evidence of habitation (Makkulasse 1986; see also Bigalke 2005). According to Makkulasse (1986), Massenrempulu was traditionally ruled by a confederation of chiefdoms including Enrekang (the main population centre in Islamic times), Maiwa and other constituents including Alla, Malua, Buntu Batu, Kassa, Batulappa and Duri at various times in the past. In 1905, the ruler of Enrekang and his commanders strengthened the fortifications near Enrekang as Dutch troops marched on the region. The Dutch captured the forts at Alla and Buntu Batu in 1907 but, once pacified, Enrekang was left largely in peace and not fully incorporated into the Dutch colonial administration until 1921.

\section{terira austiralis 53}


Somba's report on Islamic and pre-twentieth-century non-Islamic burial mortuary locations at Buntu Kotu (2009) provides no period of occupation or date of the construction of the fort's undressed stone walls. From her report, however, we hazard a seventeenth- to nineteenth-century date of construction. This may imply that at least some of the other Massenrempulu fortifications could have origins that predate the nineteenth century. All of these (apart from Alla, which was defended naturally by a steep drop around its entire perimeter) had walls of undressed stone (Makkulasse 1986).

\section{Appendix E: Fortifications in the kingdom of Bantaeng and in Jeneponto}

According to Bougas (1998), the township of Bantaeng first emerged as a population centre in the fourteenth or fifteenth century, in concert with the expansion of wet rice agriculture and maritime trade. Bantaeng subsequently incorporated the small kingdoms of Gantarang and Kaili that had developed respectively along the rivers to the immediate east and west, despite a failed revolt by Kaili in the 1500s. In the sixteenth century, several of the Bantaeng polities (and Jeneponto and Bulukumba) suffered military conquest at the hands of Goa-Talloq (McWilliam et al. 2012).

Bougas $(1998: 93,94)$ suggests that the settlement of Gantarang Keke, which lies $10 \mathrm{~km}$ upstream from the coast in a ridge of land between the Patte and Biang Keke Rivers, may once have been fortified, and that the remains of a wall behind the primary school may once formed part of the settlement's defences. He states that Gantarang Keke, which lies $2 \mathrm{~km}$ downstream, 'seems originally to have been fortified', but offers no evidence (Bougas 1998:95). We would argue that the fortification traces in Bantaeng reflect heightened defence requirements relating to the birth pains of political integration and the threat of distant military attack. We therefore date the reported (Lembang) Gantarang Keke fortifications to the time of Bantaeng's political integration and Goa-Talloq's conquest of 'Gantarang'.

Another apparent fortress, Benteng Kaili, refers to a location near the mouth of the Kaili River, just west of Bantaeng township, where informants reported the existence of earth walls, since washed away by a recent flood (Bulbeck field notes, 8 October 2011). A second coastal fortification can be inferred from Andaya's (1981:82-87) account of the several forts built by Goa-Talloq at Bantaeng in its failed attempt in 1666 to block the VOC advance on Makassar. While there is no information in Andaya (1981) or any other source on fortifications at Bantaeng township prior to 1666, we can assume that a fort of some description had long defended 'the largest and most prosperous city in the south' (Andaya 1981:82). The traces of fortifications that can be seen today at Bantaeng township ( $\left.5^{\circ} 33^{\prime} 04.2^{\prime \prime} \mathrm{S} 119^{\circ} 57^{\prime} 09.4^{\prime \prime} \mathrm{E}\right)$ are the remnants of a brick wall and Dutch barracks built by the VOC adjacent to the former residence of the allied ruler of Bantaeng (Bulbeck field notes, 8 October 2011). Local informants maintain that this was also the place where the VOC forces defeated those of Goa-Talloq. This points to this as a likely location for any pre-1666 fortifications at Bantaeng township.

The best archaeologically documented Bantaeng fortification is 'Benteng [fortress] Batu Terang', described by Bougas:

The principal feature of the site was a large and impressive benteng or fort that dominated the top of the hill. The walls of the fort were \pm 2 kilometers in length, 3 to 4 meters thick and flat on top. They varied in height, depending on the terrain, from 1 to 8 meters (Suaka, 1984:36). These fortifications were only constructed on the northern, eastern, and southern parameters of the town. $\left.{ }^{[1}\right]$ The main gate seems to have been placed in the eastern wall, facing the rising sun. No wall was built on the western side of the settlement, since the site was protected by the steep descent of the land to the Panaikang River, that bordered the western slope of the hill. The stones, that once formed the wall, have unfortunately been cannibalized by local farmers and very little remains of the benteng wall today. (1998:118)

11 Three walls of some $2 \mathrm{~km}$ in length imply a defended area of around 40-50 ha. 
Kaili's revolt in the 1500s may explain the initial construction of hilltop fortress of Batu Terang, but its commanding view over the Bantaeng township, and its abundance of sixteenthto nineteenth-century habitation debris (Bulbeck field notes, 8 October 2011), imply that it retained its status as a strongly defended area for up to four centuries. After Bantaeng had become a fully integrated political entity, including its period as a VOC stronghold, Benteng Batu Terang may have assisted Bantaeng's defence as an outlook post or withdrawal refuge. There were at least two eighteenth-century uprisings by Makasars against the Dutch presence in Makassar, and Bantaeng was sacked during both of them (Patunru 1983).

As for Jeneponto, Caldwell and Bougas (2004:498) report an extant oral tradition of the unification of Bangkala, one of the two Jeneponto kingdoms, following a ferocious battle between two smaller polities. There may have originally been fortifications of some description in Jeneponto but the only surviving examples are the remains of stone walls at Toloq and Rumbia in upland Jeneponto. The likely explanation here is that Toloq and Rumbia were semi-autonomous and largely responsible for their own protection (Caldwell and Bougas 2004). Both were vulnerable to attack because of their remoteness from Binamu, east Jeneponto's political centre, to which tributary chiefdoms looked in times of insecurity.

\section{Appendix F: Makassar fortifications}

\section{Somba Opu}

The coastal fortress of Somba Opu, $6 \mathrm{~km}$ southeast of Makassar, had earthen walls during the reign of Tumapaqrisiq Kallona and brick walls during the reign of his successor Tunipalangnga, before being fully rebuilt in 1631. Seventeenth-century Dutch sketches of Somba Opu need to be interpreted with care as all fail to depict the fortress's southern extension. However, they provide useful information on internal structures and evidence that the fortress had originally extended northward beyond the extant archaeological remains (Bulbeck 1998).

The 1667 Treaty of Bungaya allowed Somba Opu to remain standing, but continued resistance by the Makassar forces convinced the VOC of the need to destroy this important fortification. The closing chapter of the Makassar War in 1669 saw Bugis troops storm Somba Opu, aided by cannon fire from the VOC warships anchored offshore (Andaya 1981:130-132). In 1694, Sultan Abdul Jalil rebuilt Somba Opu and reoccupied it as Goa's palace centre, but in 1701 the VOC forced him to demolish it (Patunru 1983:72-73). Nonetheless, Somba Opu remained an important population centre, as shown by textual references to Somba Opu in 1724 and 1747 (Cummings 2011:210, 266), until the VOC occupied it in 1778 as part of the expulsion of I Sangkilang. The 'kingdom' of Somba Opu and the area of Sapirea (today a large village) were then placed under VOC control in 1781 (Patunru 1983:89). In accord with the above textual references, Somba Opu appears as a settlement on late seventeenth- to mid-eighteenthcentury maps of South Sulawesi, before being depicted as an island without a settlement c. 1810 (de Roever and Brommer 2008:157, 162-165, 174-175).

\section{Benteng Talloq}

In the early sixteenth century the mouth of the river Tallo (which had been inhabited since at least the fourteenth century) became the palace centre of Talloq. The earliest evidence for the construction of Talloq's fortress at the mouth of the river dates to c. 1615 (Bulbeck 1992:410, 416). Although the walls were reportedly razed in 1670 (Cummings 2011:77), either the demolition was incomplete or it was soon followed by restoration, given that a 1693 map of Makassar (de Roever and Brommer 2008:162-163) shows a large, quadrangular compound at Talloq. The demise of Benteng Talloq as a functioning fortress presumably dates to the 1701 reimposition

\section{terra australlis 53}


of the Bungaya Treaty, which, as noted above, stipulated the demolition of Goa-Talloq's rebuilt coastal fortifications. What remained of the walls in the mid-1980s consisted of coursed, dressed masonry or interior and exterior casings of bricks enclosing earth (Bulbeck 1992: Figure 12.1).

\section{Makassar's coastal wall}

A crucial ingredient in Makassar's capacity to resist seaborne assaults by the VOC between the 1630s and 1667 was its chain of coastal forts between Ujung Tana and Barombong, linked by a semi-continuous line of coastal wall (Bulbeck 1998:80-82). The coastal fortifications from Somba Opu to Barombong are well documented in textual sources and archaeological data that confirm or complement each other. The Bayoa, Garassiq, Panakukang and Barombong forts, and the connecting coastal wall, were first built at around 1634 and refurbished after the VOC occupied Panakukang briefly in 1660. ${ }^{12}$ The 1693 map of Makassar (de Roever and Brommer 2008:162-163) shows a small fort at Garassiq, presumably one of the rebuilt coastal fortifications that Goa was forced to re-demolish in 1701.

As early as the 1980s, an archaeological survey of the coastal fortifications north of Somba Opu was impossible because of Makassar's urban growth. One of the few sources of useful data is a VOC sketch showing the size of the Ujung Pandang fort (Schilder et al. 2006:302). ${ }^{13}$ The construction of Makassar's defences is credited to Talloq's Sultan Awalul Islam. This evidently took place during the 1630s after he had vacated the Talloq throne and moved to Bonto Alaq (located centrally within Makassar) to focus on the city's administration (Bulbeck 1992:429). The Talloq chronicle specifies stone walls at Talloq (confirmed archaeologically) and Ujung Tana, as well as unspecified fortifications at Panakukang and Ujung Pandang (Cummings 2007:88). Based on the archaeological survey of coastal fortifications south of Somba Opu, it is likely that Ujung Pandang was predominantly earthen, while the coastal wall from Ujung Tana to Somba Opu was built of brick (Table 7.5). Ujung Tana may have been the last surviving coastal fortification as it is shown on a 1720s map of Makassar (de Roever and Brommer 2008:157).

\section{Appendix G: Fortifications to the south of Makassar}

\section{Sanrabone}

An excellently preserved fortress, Sanrabone lacks documentary evidence on its construction history, other than a 1774 observation by Stavorinus (1798:211) that it was built at around the same time as Talloq and Somba Opu. Analysis of brick metrical data supports approximate contemporaneity of construction of all three fortresses (Bulbeck 1998:83, 91). The fact that the VOC/Bugis forces deliberately bypassed Sanrabone during their 1667 assault on Makassar (Andaya 1981:87) also suggests its fortress had been built by that date. The lack of a VOC claim on Sanrabone as a spoil of war may have prompted Goa to install Abdul Jalil as Sanrabone's ruler in 1668 , prior to his ascension to the Goa throne in the following year. We can be confident that Benteng Sanrabone had been erected by the mid-1670s based on reports that Goa-Talloq's remnant naval forces were harboured in the Sanrabone River in 1675, and that the Goa regalia were held in safekeeping at Sanrabone in 1678 (Bulbeck 1998:82-83).

12 The data in Table 7.5 on the pre- and post-fortification occupation of the sites along the southern coastal fortifications are from Bulbeck (1992). Dutch sketches of the VOC occupation of Panakukang and the 1667 siege of Makassar (Boxer 1967: Plate III; de Roever and Brommer 2008:180) can be useful for understanding the southern coastal fortifications (but also misleading, as in their depiction of Panakukang as a large fort).

13 The VOC was not interested in the Ujung Pandang fortress as such. The purpose of the sketch was to document the initial construction of Fort Rotterdam, the VOC stronghold in Makassar. This involved building stone walls around the Ujung Pandang fort, which had been surrendered in good condition by Goa-Talloq to the VOC in 1667 as required by the Treaty of Bungaya. 
The continued importance of Sanrabone is clear from its royal eighteenth-century graves (Bulbeck 1992: Photo E-3), its consistent depiction on VOC maps dating from 1693 onwards (de Roever and Brommer 2008:152, 154-158, 160, 162-165, 168, 174) and its early eighteenth-century role as a southern outpost of Goa (Cummings 2011:169-258). Sanrabone was the original centre of the popular revolt led by I Sangkilang in 1776; its independence ended in 1781 when Goa transferred Sanrabone to the VOC as part of their peace treaty (Patunru 1983:85, 89).

\section{Galesong}

Galesong appears to have been an important harbour for some two millennia (Bulbeck 2010:163). At this 'fortified city' (Andaya 1981:88) in 1667, some 30,000 Makassar troops were defeated by 10,000 Bugis ground troops and 250 VOC infantry. This engagement cleared the way for the Bugis troops' northward march on Makassar to besiege the city from its south (Andaya 1981). Bulbeck (1992:712-713, Figure E-4) undertook a comprehensive survey of Galesong that failed to reveal evidence of brick or stone defences, but mapped a total length of $3.5 \mathrm{~km}$ of raised earthen features running parallel with or perpendicular to the shoreline. Although Bulbeck interpreted these features as natural cheniers that could well have acted as natural defences, bolstered by timber palisades, it seems more likely that they are remnants of earthen wall defences, consistent with their height of up to a metre or more. Galesong almost certainly would have had defences of some description throughout much or all of its lengthy period of settlement. However, the archaeologically recorded remnants can all be attributed to the 1667 battle, one of the decisive engagements in the Makassar War.

\section{Appendix H: Sengkae (Siang)}

Excavations at Sengkae, the fortified palace centre of the Makasar-speaking kingdom of Siang, $25 \mathrm{~km}$ north of Maros, revealed a stonewall foundation and fifteenth- to seventeenth/eighteenthcentury ceramics. The size of the defended quadrangular area appears to have been approximately $400 \mathrm{~m}$ north-south by $250 \mathrm{~m}$ east-west, with the northern border formed by a former river channel (Fadillah and Mahmud 2000:45). A Malay presence had apparently been established at Siang by 1494 (Baker 2005:73), and by 1534 the Portuguese were beginning to show an interest in the area (Pelras 1977:228-230). Although Goa conquered Siang by at least 1546 (Bulbeck 1992: 124), it remained a main stopover for Portuguese in South Sulawesi until 1547 (Pelras 1977:233), which suggests that Sengkae's fortifications remained intact after Goa’s conquest. ${ }^{14}$ However, the kingdom of Siang was based at Sengkae only between the fifteenth century and c. 1600, after which date the river channel north of the fortress became silted up, hindering navigable access to the sea (Fadillah and Mahmud 2000:101). Based on this evidence, we propose a dating of c. 1500-1600 for the Sengkae fortress. Nonetheless, the kingdom of Siang remained sufficiently important in the following centuries to be one of major suppliers of rice to the VOC in 1669 (Andaya 1981:265) and to appear on Aubert's map of 1752 (de Roever and Brommer 2008:164-165).

\section{Appendix I: Balangnipa (Sinjai)}

According to local historians in Sinjai, the Dutch fort at Balangnipa on the coastal plain had originally been a Bugis fort. They claim that the Dutch replaced the Bugis timber structures when they built their own fort of concrete blocks in 1863, covering a quadrangular area of 0.5 ha. The Bugis predecessor was first built in 1557 and strengthened after the triple alliance of BuloBulo, Lamatti and Tondong in 1696. The fortress defended the mouth of the Tangka River near Balangnipa, which had been a minor port from at least the sixteenth century (Muhaeminah 2009).

14 Antonio de Paiva did not describe any fortifications at Siang in 1544, nor at Suppaq and Makassar, which he also visited (Baker 2005). This lack of evidence can be attributed to Paiva's minimal physical description of any of these places. 


\section{Appendix J: Barunia (Selayar Island)}

The fort of Barunia on the island of Selayar is one of 20 surveyed sites associated with the kingdom of Buki, which was locally prominent between the fifteenth and eighteenth centuries. Physical traces of Buki's defences are scarce except at Barunia, which is enclosed by a limestone wall and retains six cannons from an original number of perhaps 30. The Buki rulers moved from the coast inland to Barunia in the late eighteenth century in response to increasing VOC control (Muhaeminah and Mahmud 2009). Their relocation should be viewed in the context of the physical proximity of Buki to Benteng, Selayar's administrative capital, which grew in importance as a company outpost during the eighteenth century (Heersink 1994: 49-51). The name Benteng (fortress, fortified settlement) implies that Buki previously had some sort of coastal fortification there, but there are no reports of pre-Dutch fortifications within Benteng.

\section{Appendix K: Bone}

The oldest recorded Bone fortification is that of Papolo. Goa staged a failed assault on this fort in 1565, as recorded in both of the Goa and Bone chronicles (Cummings 2007:36; Macknight 1993:22). ${ }^{15}$ The Goa chronicle also notes that Bone constructed a stockade at Pasempa (Cummings 2007:49) where Goa, assisted by Wajoq, Soppeng and Luwuq, attacked and defeated Bone in 1643 and 1644 (Andaya 1981:40-41). Described by the English in 1814 as 'very difficult to vanquish' (De Klerck 1975:146), Pasempa was depicted in 1859 as a set of three walls flanking the trail from Palakka (near Watampone) to Wajoq (Perelaer 1872: volume 2, folding chart 3). The walls, with their combined length of $500 \mathrm{~m}$, produced three bottlenecks along the trail and also blocked off movement into the gorge, where a ford had been built across the Pasempa river. As late as 1905, Pasempa served as a retreat for the Bone forces following the fall of Watampone (Budiarta 2007:130).

For nearly a century, Bone maintained a palace centre $30 \mathrm{~km}$ northwest of Watampone near the mouth of the Cenrana River. This fortified settlement was built by Bone in 1671 to block off Wajoq's access by river to the sea (Andaya 1981:143). Aubert's 1752 map shows Cenrana (and not Watampone) as a fortified palace centre, flanked by a smaller 'Benteng Tulawa' across the river (Wallis 1965: Figure XIX). A late seventeenth-century VOC map of Cenrana (Andaya 1981: Map 8) and a series of surveys and excavations (Bulbeck and Caldwell 2000:80-82; Mahmud 2000:44-61) make it one of South Sulawesi's best-documented fortifications (Table 7.5). By the 1760s, Bone had returned to Watampone, to judge by the lack of any reference to Cenrana in VOC 1760s correspondence on Bone (Wallis 1965: 368-435).

The Chronicle of Bone makes it clear that the kingdom's palace centre, Watampone, was surrounded by a wall in the late sixteenth century (Macknight 1993:22). According to Drs Asmat (pers. comm., 22 December 2010), the original Watampone fortress was built to a height of $3 \mathrm{~m}$ by La Tenrirawe Bongkangnge (r. 1568-1584) before La Maddaremmeng Matinroe ri Bukaka (r. 1625-1640) increased the walls' height to $7 \mathrm{~m}$. This was the fortress that defended Watampone at the time of the Dutch attack in 1905, represented as late as the 1950s by remnant earthen walls up to $5 \mathrm{~m}$ high. These claims, which are not found in any written source of which we are aware, may reflect a still-extant oral tradition. In support of Drs Asmat's claim as to the operational status of the Watampone fortress as late as 1905, the fortress is clearly depicted on a topographical map dated to c. 1859 (Perelaer 1872: volume 1, folding chart 1). ${ }^{16}$ However, when

15 A local historian, Drs Asmat Riady Lamallongeng, accompanied Bulbeck to what he claimed was the site of the fort (S $04^{\circ} 31^{\prime} 25.2^{\prime \prime}$ E $120^{\circ} 19^{\prime} 12.0^{\prime \prime}$ ) but no physical traces were visible.

16 Toponyms in present-day Watampone that match the fortress outline include Saliwengbenteng, Lalebata and Jalan Benteng. A remnant section of earthen wall corresponding to the fortress's southeast corner was recorded by David Bulbeck and Sue O'Connor at $04^{\circ} 33^{\prime} 07.5^{\prime \prime} \mathrm{S} 120^{\circ} 20^{\prime} 19.5^{\prime \prime} \mathrm{E}$ on 22 December 2010. 
James Brooke visited Watampone in 1840 (Mundy 1848:131), he reported no fortifications, noting that the inhabitants had only recently started returning after the Dutch had burnt the capital to the ground in 1824. On balance, we conclude that the foundations of the Watampone fortress remained intact between the late sixteenth and early twentieth centuries, although we have no evidence for the fortress' use in the defence of Bone between the 1640s and 1750s. ${ }^{17}$

\section{Appendix L: Benteng Tosora (Wajoq)}

At the time of his visit to Wajoq in 1840, Brooke described Tosora as:

a large straggling city, greatly in decay; the ancient boundary of which is marked by a fortification, which embraces a space of several miles in circumference, and occupies to the eastward a slightly elevated ridge, and to the westward sinks to a swamp. Not many years since, the main stream of the Sadang [sic: Cenrana] river ran near the southern limit of the town, though it has now receded three miles or more, leaving a deep but narrow channel bounded by swamps. (Mundy 1848:79-80)

From this description, Tosora's original area can be identified with the quadrangular area of Desa Tosora to the north of a chain of ponds linked by a channel (Hadimulyono 1985:103), even though the remnant fortifications have been reduced to two ruined earth walls of $3 \mathrm{~km}$ total length (Duli 2010:148). Brooke added that the population of Tosora was about 6000 but must have originally been at least four times that number, and that the Wajoq nobility resided outside of Tosora except when convening there for meetings. This account is consistent with the archaeological evidence for Tosora's final abandonment during the late nineteenth century (Hadimulyono 1985:78; Duli 2010:157).

\section{Appendix M: Luwuq palace centre defences}

Earthen walls have also been recorded in association with Luwuq's fifteenth- to sixteenth-century capital at Utti Batue (Bulbeck et al. 2007), and at Benteng Massalekoe, to the immediate north of Malangke Beccu, where Luwuq's capital was briefly located c. 1600 (Bulbeck and Prasetyo 1998). We propose that a levee of the Rongkong River at a site called Dadekoe provided a natural defence for the Utti Batue residents when the settlement was first established. The fifteenthcentury use of Dadekoe for burials (Bulbeck and Prasetyo 1999:25) implies the erection of the earthen wall at Utti Batue's doorstep by that date.

The earthen fortress of Benteng Tompotikka at Palopo, mapped by Mahmud (1993) is the largest of the Luwu fortifications. We date the period of the fortress' construction and maintenance to Palopo's first two centuries as Luwuq's capital after c. 1620. Brooke's account of his four days in Palopo in 1840 includes no mention of fortifications, although he did note that Luwuq was in a state of anarchy having recently emerged from a civil war between two contenders for the throne (Mundy 1848:154-155). Disuse of Benteng Tompotikka by the nineteenth century is confirmed by the lack of any reference to fortifications in van Braam Morris's detailed 1889 account of Palopo or the literature on the 1905 Dutch occupation of Palopo.

\section{Appendix N: Non-Bugis fortifications in Luwu}

The Wotu people are coastal traders who first settled current-day Wotu town in the fifteenth century (Bulbeck and Caldwell 2000:51). The remnant fortifications at the town of Wotu, mapped by Fadillah (2000:165), are best interpreted as a sigmoid wall of c. $550 \mathrm{~m}$ length. Local information and archaeological evidence collected by Fadillah $(2000: 182,185)$ date its construction and maintenance to between c. 1600 and the early twentieth century. Defensive

17 Watampone additionally had forward defences at its estuary of Bajoe in 1859 (Perelaer 1872: Plate V) and 1905 (Budiarta 2007:130).

\section{terira australlis 53}


earthen walls are also reported at Tampinna, which was occupied by Bajao sea gypsies between c. 1400 and 1700, before being laid waste by Wotu. Although no archaeological traces have been recovered, the walls were said to have run along the site's southern border as defined by the Tampinna River (Bulbeck and Caldwell 2000:45).

Baebunta was a Lemolang polity closely linked to Luwuq when the latter's capital was based at Malangke. The fort of Benteng Baebunta (Figure 7.A3) reputedly dates to the nineteenth century, although evidence for habitation within the fortified area dates back to the fifteenth century (Bulbeck and Caldwell 2000:55).

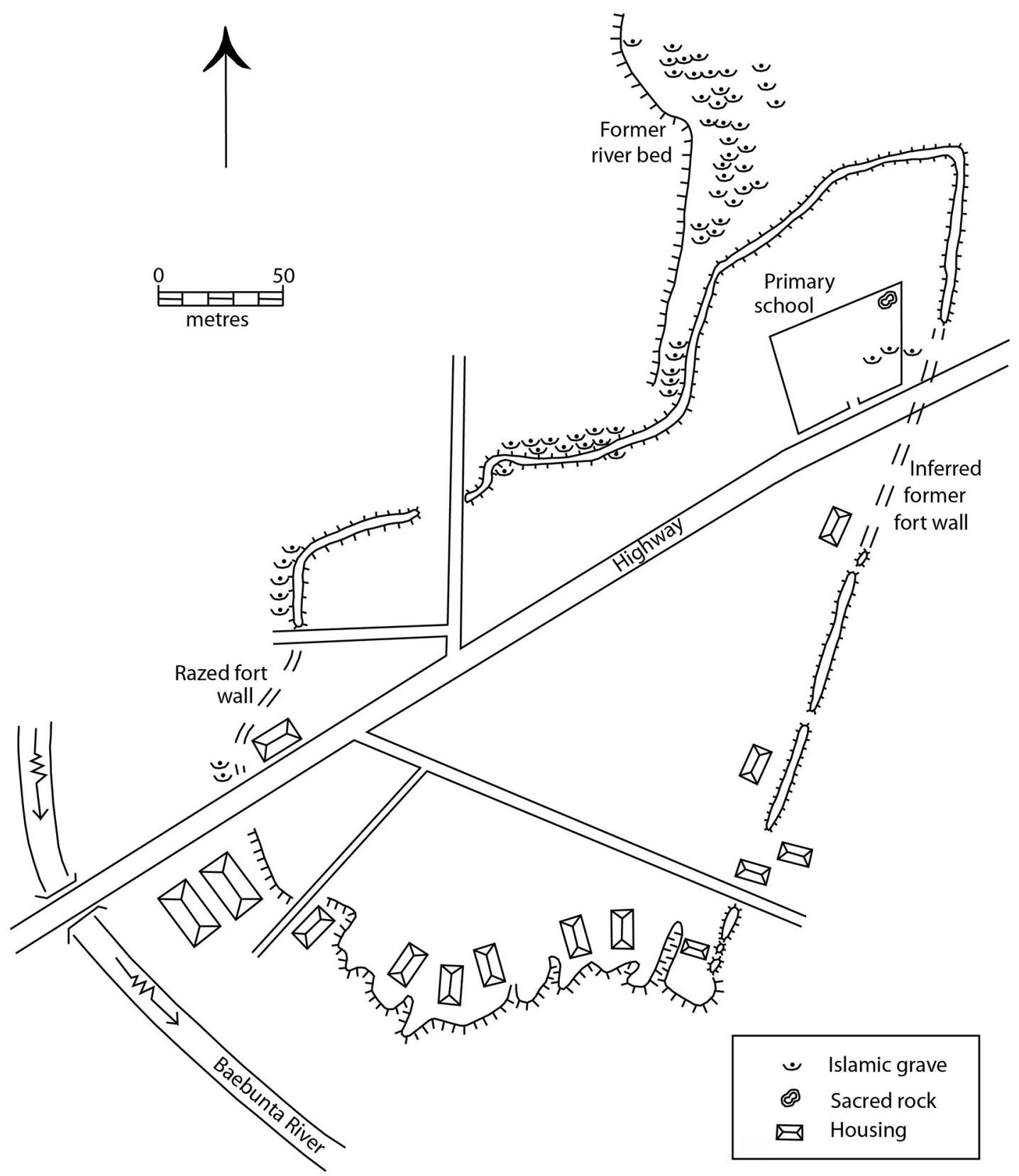

Figure 7.A3. Plan of Benteng Baebunta, Luwu (theodolite and staff survey).

Source: David Bulbeck. 


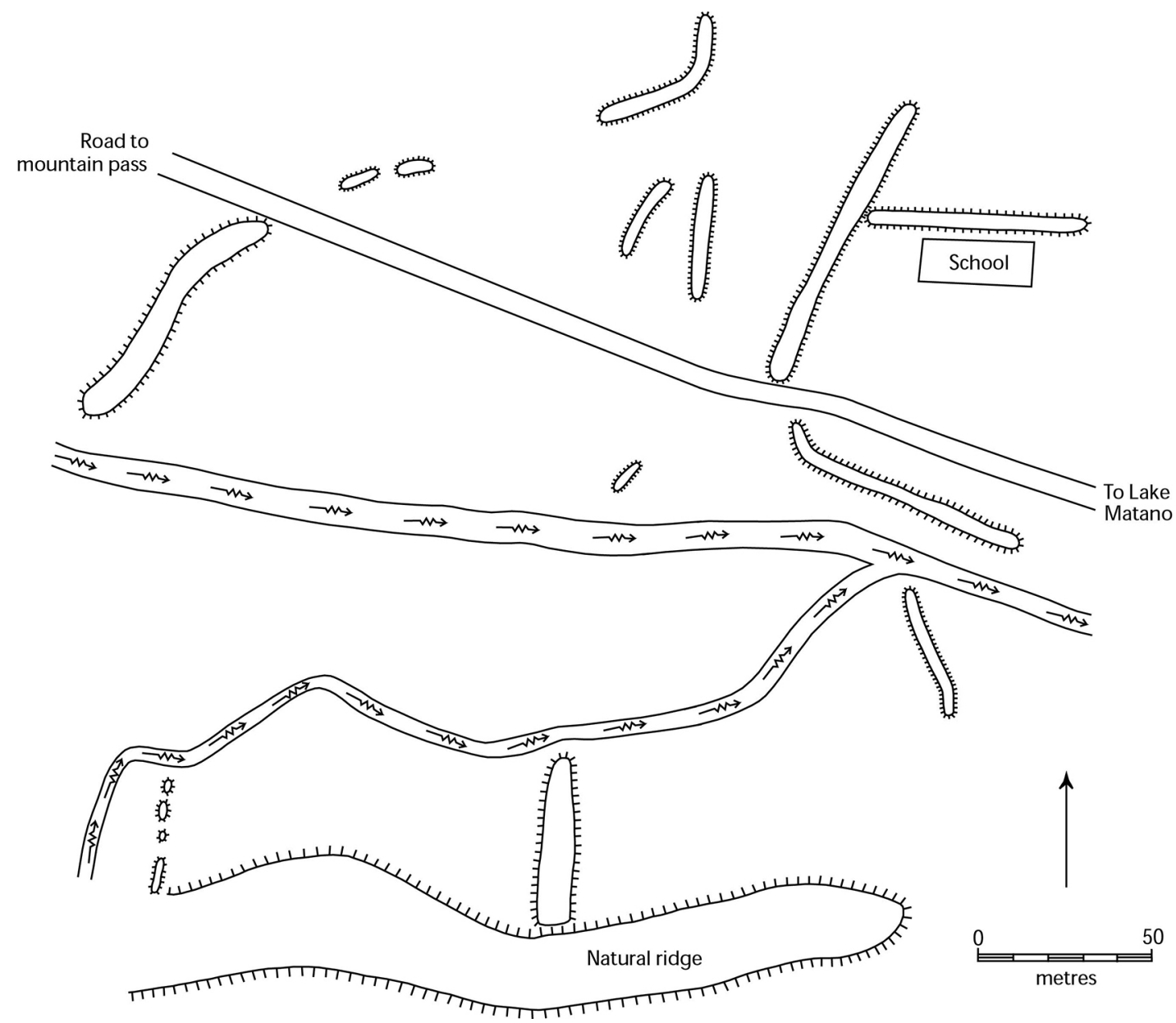

Figure 7.A4. Plan of Benteng Matano, Luwu (theodolite and staff survey).

Source: David Bulbeck.

A complex of defensive walls (probably crowned by bamboo spikes), known as Benteng Matano, was recorded at the western margin of Matano village on the west shore of Lake Matano (Figure 7.A4). According to the local inhabitants, who speak the Padoe language, the walls were built in the nineteenth century to protect them from their neighbours' headhunting raids. The late construction of Matano's defences would appear to reflect the anarchic condition of nineteenth-century Luwuq. Nuha, on the north shore of Lake Matano, also has the remnants of an earth wall up to $60 \mathrm{~cm}$ in height and $3.8 \mathrm{~m}$ in width at the base. On 27 February 1999, the South Sulawesi archaeologists Gunadi, Tanwir Wolman, Sarjiyanto and Agustiawan collected local information that the wall had once run to the immediate north of Nuha, extending from the Laki River at the west to the Nuha foothills at the east. Permanent habitation at Nuha and Matano dates back to the twelfth century, respectively associated with the production and the export of Lake Matano iron (Bulbeck and Caldwell 2000: 23, 28, 33). 
This text is taken from Forts and Fortification in Wallacea: Archaeological and Ethnohistoric Investigations, edited by Sue O'Connor, Andrew McWilliam and Sally Brockwell, published 2020 by ANU Press, The Australian National University, Canberra, Australia. 